Prepared in cooperation with the U.S. Fish and Wildlife Service

\title{
Analysis of Seafloor Change at Breton Island, Gosier Shoals, and Surrounding Waters, 1869-2014, Breton National Wildlife Refuge, Louisiana
}

By James G. Flocks and Joseph F. Terrano

Open-File Report 2016-1069

U.S. Department of the Interior

U.S. Geological Survey 


\title{
U.S. Department of the Interior \\ SALLY JEWELL, Secretary
}

\author{
U.S. Geological Survey \\ Suzette M. Kimball, Director
}

U.S. Geological Survey, Reston, Virginia: 2016

For more information on the USGS—-the Federal source for science about the Earth, its natural and living resources, natural hazards, and the environment-visit

http://www.usgs.gov/ or call 1-888-ASK-USGS (1-888-275-8747).

For an overview of USGS information products, including maps, imagery, and publications, visit http://store.usgs.gov/.

Any use of trade, firm, or product names is for descriptive purposes only and does not imply endorsement by the U.S. Government.

Although this information product, for the most part, is in the public domain, it also may contain copyrighted materials as noted in the text. Permission to reproduce copyrighted items must be secured from the copyright owner.

Suggested citation:

Flocks, J.G., and Terrano, J.F., 2016, Analysis of seafloor change at Breton Island, Gosier Shoals, and surrounding waters, 1869-2014, Breton National Wildlife Refuge, Louisiana: U.S. Geological Survey Open-File Report 2016-1069, 27 p., http://dx.doi.org/10.3133/ofr20161069.

ISSN 2331-1258 (online) 


\section{Acknowledgments}

This study builds on the reports of DeWitt and others (2016), Terrano and others (2016a), and Miner and others (2009); the authors would like to thank the field teams, processing teams, report writers, and reviewers of these prior efforts. The authors would also like to thank Noreen Buster and Julie Bernier of the U.S. Geological Survey, whose reviews of this report contributed greatly. This project included funding from the Louisiana Outer Coast Early Restoration Project, obtained by the natural resource trustees for the Deepwater Horizon Oil Spill, pursuant to the Framework for Early Restoration Addressing Injuries Resulting from the Deepwater Horizon Oil Spill, executed April 20, 2011. 


\section{Contents}

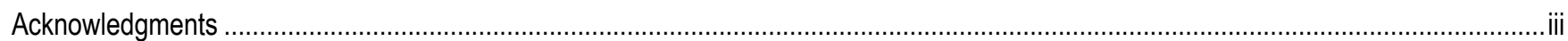

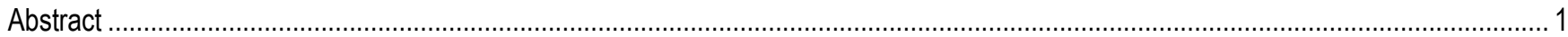

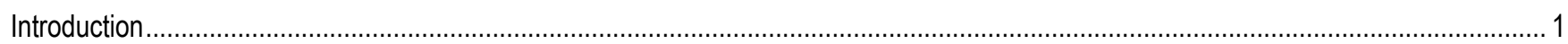

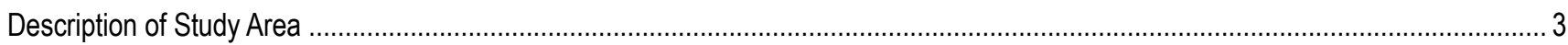

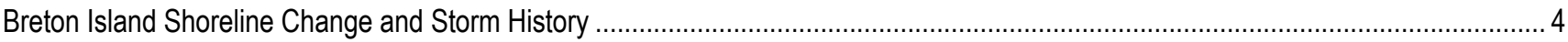

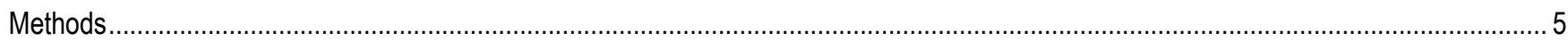

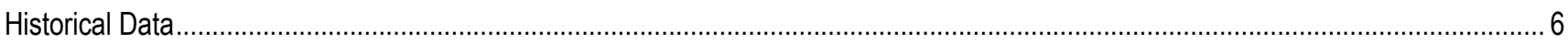

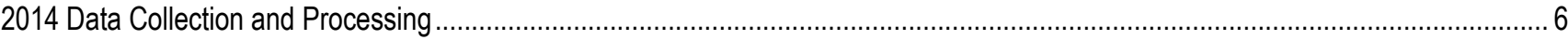

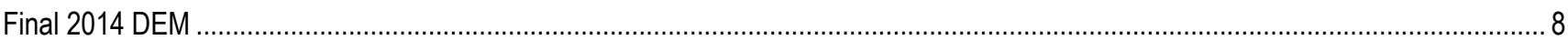

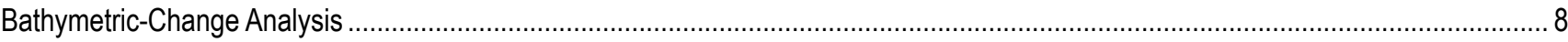

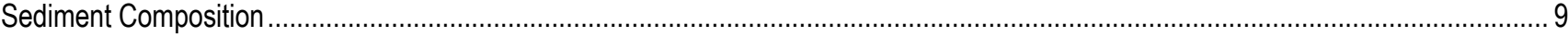

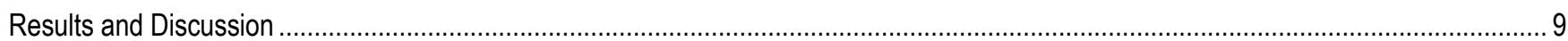

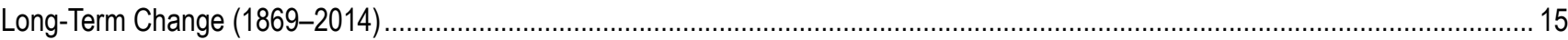

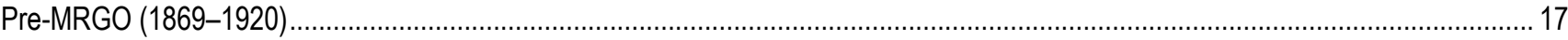

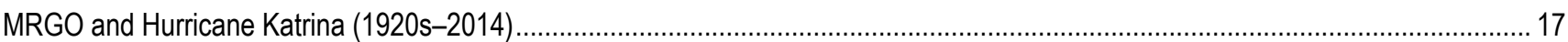

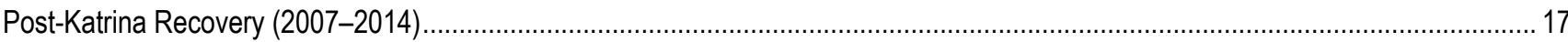

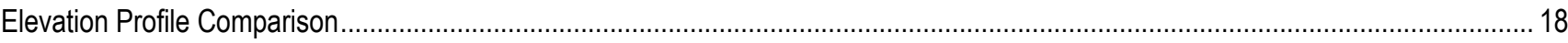

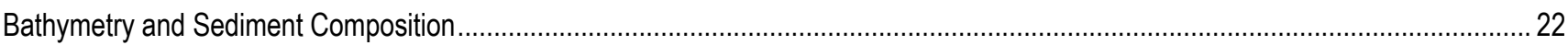

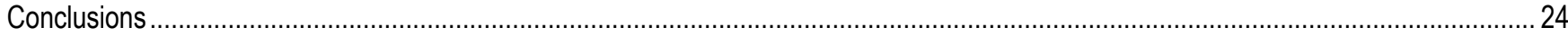

References Cited.

\section{Figures}

1. Maps showing location of Breton Island within the Breton National Wildlife Refuge, Gosier Shoals, and the Mississippi River-

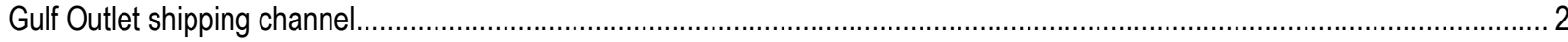

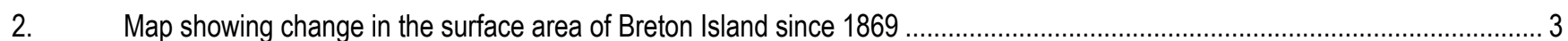

3. Photograph from the U.S. Geological Survey National High Altitude Photography program showing Breton Island in 1983, with the 2014 shoreline overlain as a black line

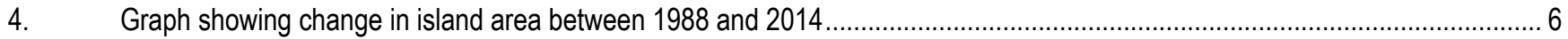

5. Trackline map showing survey extent and coverage of single-beam and interferometric-swath bathymetric systems around Breton Island, Gosier Shoals, and offshore

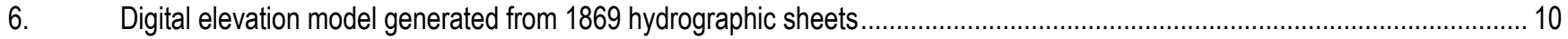

7. Digital elevation model generated from 1921-1922 hydrographic sheets ....................................................................... 10

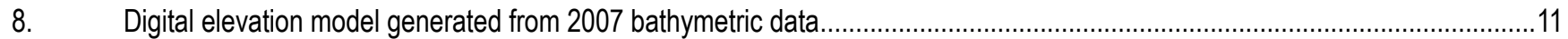

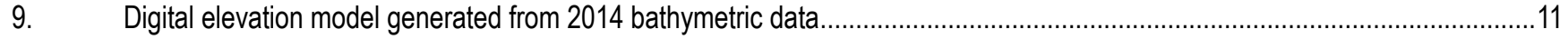

10. Map showing long-term elevation change determined by calculating the difference in digital elevation models between 1869 and 2014, considered to be accretion and erosion over the time period

11. Map showing pre-Mississippi River-Gulf Outlet elevation change determined by calculating the difference in digital elevation models between 1869 and 1920, considered to be accretion and erosion over the time period. 
12. Pre/post-Mississippi River-Gulf Outlet and Hurricane Katrina impact determined by calculating the difference in digital elevation models between 1922 and 2014, considered to be accretion and erosion over the time period......

13. Post-Hurricane Katrina recovery determined by calculating the difference in digital elevation models between 2007 and 2014 , considered to be accretion and erosion over the time period

14. Seismic subbottom profiles collected in 2007 and reoccupied in 2014 across the Mississippi River-Gulf Outlet shipping channel reflect the infilling of the channel after its decommission and cease in maintenance dredging following Hurricane Katrina. 19

15. Elevation profiles derived from the digital elevation models for the four time periods across the Breton/Gosier platforms and for the Mississippi River-Gulf Outlet.

16. Elevation profiles derived from the digital elevation models for the four time periods across the southern Breton platform and offshore

17. Elevation profiles derived from the digital elevation models for the four time periods across Breton island and the offshore shoal

18. Elevation profiles derived from the digital elevation models for the four time periods across Breton Sound, the Gosier platform, the Mississippi River-Gulf Outlet, and the offshore shoal.....

19. Elevation profiles derived from the digital elevation models for the four time periods across Breton Sound, Gosier Shoals, and offshore.

20. Average grain size of sediment samples collected from the seafloor within the Breton National Wildlife Refuge study area, color-coded by size, with the accompanying Wentworth size classification

21. Sorting of sediment samples collected from the seafloor within the Breton National Wildlife Refuge study area, color-coded by the classification from Folk (1968).

\section{Tables}

1. Sources of bathymetric and shoreline data used in the analysis of seafloor change at Breton Island, Gosier Shoals, and surrounding waters, Breton National Wildlife Refuge, Louisiana,1869-2014

2. Bathymetric dataset statistics by survey platform used to create the Breton 2014 DEM

3. Accretion and erosion volumes, changes, and rates of change during the four study time periods for the four target features and other areas within the Breton National Wildlife Refuge, Louisiana, study area..... 


\section{Conversion Factors}

International System of Units to U.S. customary units

\begin{tabular}{ccc}
\hline Multiply & By & To obtain \\
\hline & Length & \\
\hline micron $(\mathrm{um})$ & 0.001 & millimeter (mm) \\
centimeter $(\mathrm{cm})$ & 0.394 & inch (in.) \\
meter $(\mathrm{m})$ & 3.281 & yard (yd) \\
meter $(\mathrm{m})$ & 1.094 & mile (mi) \\
kilometer $(\mathrm{km})$ & 0.621 & mile, nautical (nmi) \\
kilometer $(\mathrm{km})$ & 0.540 & acre \\
\hline & Area & square mile $\left(\mathrm{mi}^{2}\right)$ \\
\hline square kilometer $\left(\mathrm{km}^{2}\right)$ & 247.1 & \\
square kilometer $\left(\mathrm{km}^{2}\right)$ & 0.386 & cubic yard $\left(\mathrm{yd}^{3}\right)$ \\
\hline cubic meter $\left(\mathrm{m}^{3}\right)$ & Volume & cubic foot $\left(\mathrm{ft}^{3}\right)$ \\
\hline cubic meter $\left(\mathrm{m}^{3}\right)$ & 1.31 & \\
\hline & 35.31 & acre-foot per year $(\mathrm{acre}-\mathrm{ft} / \mathrm{yr})$ \\
\hline
\end{tabular}

\section{Datums}

Vertical coordinate information is referenced to the North American Vertical Datum of 1988 (NAVD 88, GEOID09), and the units of all vertical measurements are in meters.

Horizontal coordinate information is referenced to the geographic coordinates North American Datum of 1983 (NAD 83, 2011); however, data were projected into the Universal Transverse Mercator (UTM) coordinate system for analysis purposes.

\section{Supplemental Information}

Data used in this report can be found in Miner and others (2009), and are available as an accompanying USGS Open-File Report Terrano and others, 2016a; (http://dx.doi.org/10.3133/ofr20161039). Additional accompanying data is available through a Data Series obtained from DeWitt and others, 2016; (http://dx.doi.org/10.3133/ds1005). Light and detection ranging (lidar) data from 2014 are available for download as a data release from Terrano and others, 2016b (http://coastal.er.usgs.gov/data-release/doi-F70G3H6G/), along with digitized shorelines and rates of change from Terrano and others, 2015 (http://coastal.er.usgs.gov/data-release/doi-F7XS5SGM/).

\section{Abbreviations}

$\begin{array}{llll}\text { BICM } & \text { Barrier Island Comprehensive Monitoring } & \text { Micron } & \text { Micrometer } \\ \text { DEM } & \text { Digital Elevation Model } & \text { MRGO } & \text { Mississippi River-Gulf Outlet } \\ \text { DGPS } & \text { Differential Global Positioning System } & \text { NWR } & \text { National Wildlife Refuge } \\ \text { GMT } & \text { Generic Mapping Tools } & \text { SBB } & \text { Single-Beam Bathymetry } \\ \text { GPS } & \text { Global Positioning System } & \text { T-sheet } & \text { topographic sheet } \\ \text { H-sheet } & \text { Hydrographic sheet } & \text { USGS } & \text { U.S. Geological Survey } \\ \text { IFB } & \text { Interferometric-Swath Bathymetry } & \text { UTM } & \text { Universal Transverse Mercator } \\ \text { Lidar } & \text { Light and detection ranging } & \text { ybp } & \text { Years before present }\end{array}$




\title{
Analysis of Seafloor Change at Breton Island, Gosier Shoals, and Surrounding Waters, 1869-2014, Breton National Wildlife Refuge, Louisiana
}

\author{
By James G. Flocks and Joseph F. Terrano
}

\begin{abstract}
Characterizing bathymetric change in coastal environments is an important component in understanding shoreline evolution, especially along barrier island platforms. Bathymetric change is a function of the regional sediment budget, long-term wave and current patterns, and episodic impact from high-energy events such as storms. Human modifications may also cause changes in seafloor elevation. This study, conducted by the U.S. Geological Survey in collaboration with the U.S. Fish and Wildlife Service, evaluates bathymetric and volumetric change and sediment characteristics around Breton Island and Gosier Shoals located offshore of the Mississippi River Delta in Louisiana. This area has been affected by significant storm events such as Hurricane Katrina in 2005. Sedimentation patterns at Breton Island and offshore have also been modified by the excavation of a shipping channel north of the island. Four time periods are considered that encompass these episodes and include long-term change and short-term storm recovery: 1869-2014, 1869-1920, 1920-2014, and 2007-2014. Finally, sediment characteristics are reported in the context of seafloor elevation.
\end{abstract}

\section{Introduction}

Barrier island systems in the northern Gulf of Mexico are highly dynamic and undergo rapid changes in area, position, and elevation over century timescales (Morton, 2008). Over the past century in Louisiana, the barrier islands have experienced loss in area and landward migration because of storm impact, land subsidence, and sea-level rise (Penland and Boyd, 1981; Penland and Ramsey, 1990; Williams and others, 1992). Changes also occur along the island platform as sediments are moved through long-term wave-dominated transport, punctuated by rapid redistribution during storm impacts. Monitoring shoreline change at varying time scales can be accomplished by using repetitive sets of nautical charts and aerial and satellite imagery collected over the past century and by using recently collected light and detection ranging (lidar) data. Monitoring seafloor change is difficult, however, because of a paucity of repetitive bathymetric datasets, yet it is a critical component to understanding island evolution.

Breton Island is a small barrier island located east of the Mississippi River Delta (fig. 1). The island and the Gosier Shoals to the north are part of the Breton National Wildlife Refuge (NWR), which extends north to the Chandeleur Islands. Breton NWR is recognized as a globally important bird habitat because of the critical resources it provides and because it hosts one of Louisiana's largest historical brown pelican nesting colonies. Breton Island has been severely impacted by long-term erosional processes and by a series of extreme events over the past century, including Hurricane Katrina in 2005, which completely submerged the island. Additionally, the Mississippi River-Gulf Outlet (MRGO) ship channel was dredged in 1968 between Breton Island and the Gosier Shoals, affecting sediment transport 
in the area. In response to these factors, island area has decreased by 87 percent since the late $1800 \mathrm{~s}$ (Terrano and others, 2016a), directly affecting the availability of nesting habitat (fig. 2). Without proper management, Breton Island will continue to deteriorate (Lavoie and others, 2010) and will no longer be able to support critical habitat. A comprehensive geologic assessment of the island platform and surrounding area is necessary to adequately characterize the geologic framework and physical processes affecting the island and to provide refuge managers the information they need for restoration design, implementation, and future monitoring. This assessment includes high-resolution mapping of seafloor elevations with comparison to historical datasets to determine seafloor change. This effort builds on the study provided by the Louisiana Coastal Protection and Restoration Authority Barrier Island Comprehensive Monitoring (BICM) project (Miner and others, 2009; Kindinger and others, 2013), which evaluated seafloor change from 1869 to 2007 and relied on studies provided by a U.S. Geological Survey (USGS) erosion study using data from 1878 to 1989 (List and others, 1994).

This report is part of a series of USGS reports that present bathymetric data (DeWitt and others, 2016), topographic/bathymetric lidar data (Terrano and others, 2016b), and shoreline change analysis (Terrano and others, 2016a) for Breton Island and the surrounding waters. The purpose of this study is to present a comparison of bathymetric elevation models from 1869, 1920, 2007, and 2014 (table 1) to evaluate and illustrate seafloor change over these time periods. Areas of physiographic significance (such as the Breton and Gosier platforms) are delineated to specify volumetric change across distinct morphologies, and two-dimensional profiles of the bathymetric datasets are provided along transects across areas that have shown significant change over the study period.

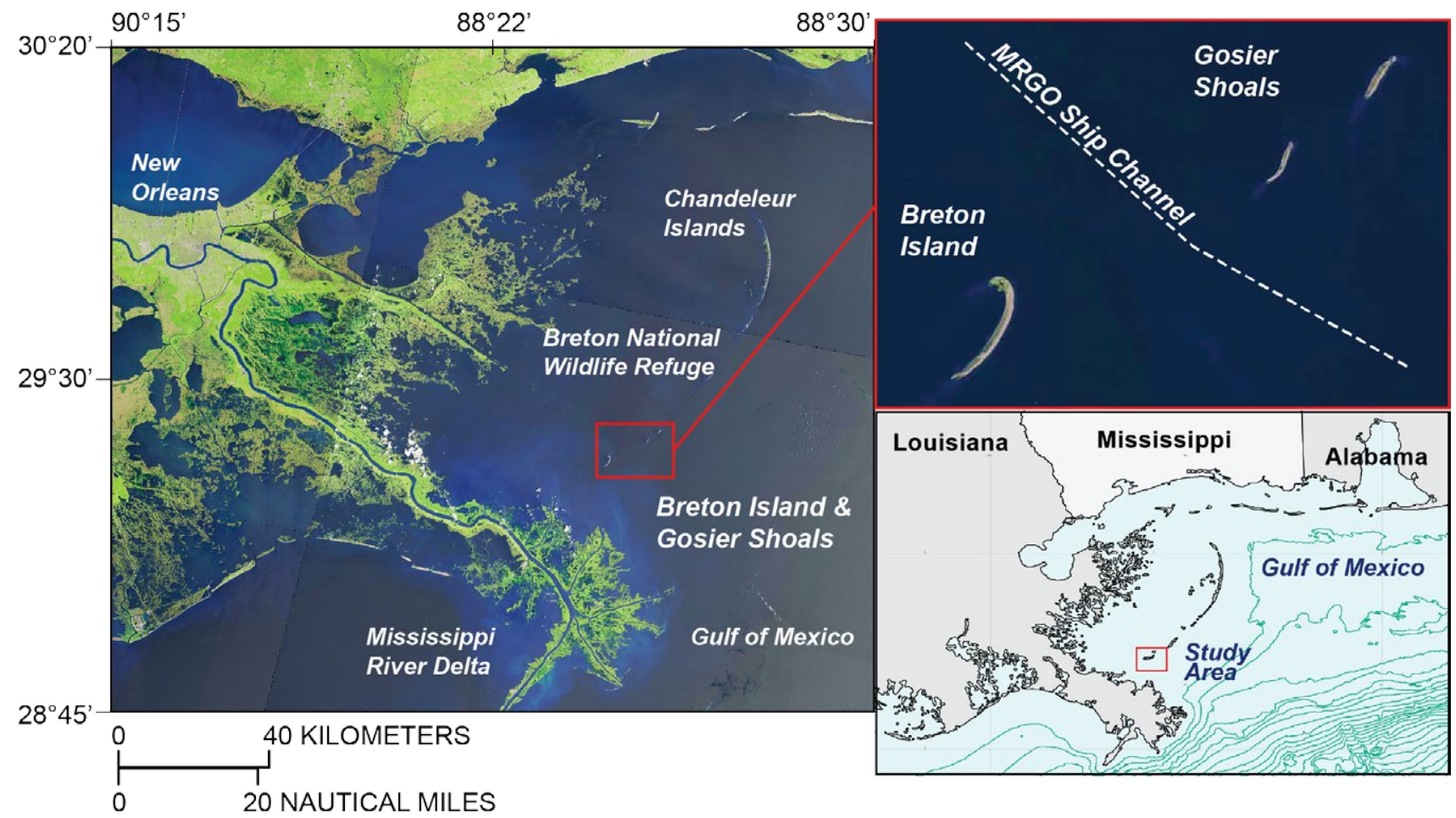

Figure 1. Maps showing location of Breton Island within the Breton National Wildlife Refuge, Gosier Shoals, and the Mississippi River-Gulf Outlet (MRGO) shipping channel. Background image is 2014 USGS Landsat 8 satellite imagery. 


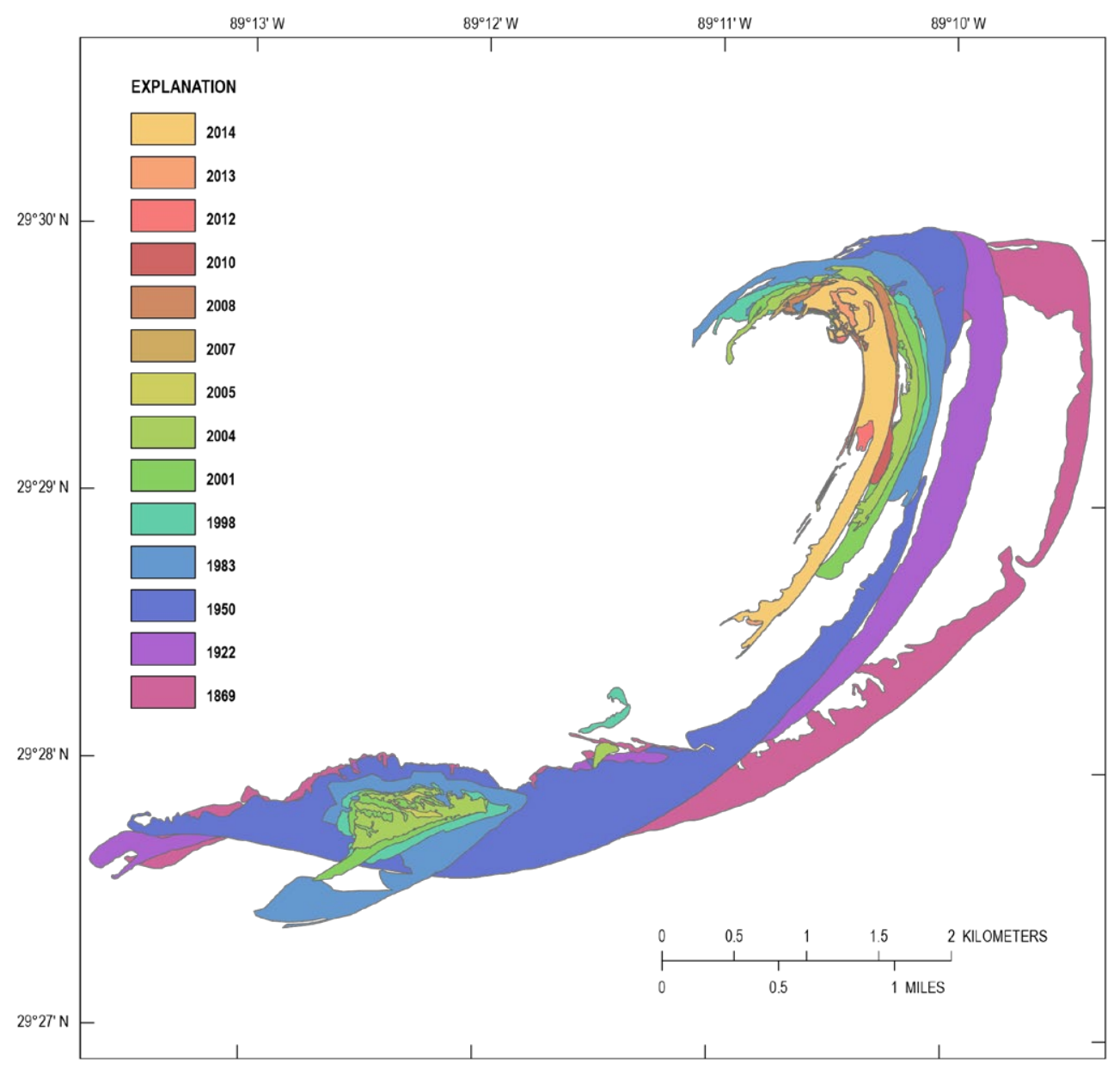

Figure 2. Map showing change in the surface area of Breton Island since 1869. From Terrano and others (2016a).

Table 1. Sources of bathymetric and shoreline data used in the analysis of seafloor change at Breton Island, Gosier Shoals, and surrounding waters, Breton National Wildlife Refuge, Louisiana,1869-2014.

[H-sheets, hydrographic sheets]

\begin{tabular}{cccc}
\hline Year-bathymetry & Year-shoreline $^{1}$ & Data Type & Bathymetry source \\
\hline 1869 & 1869 & H-sheets & Louisiana Department of Natural Resources, 2013 \\
$1920-22$ & 1922 & H-sheets & Louisiana Department of Natural Resources, 2013 \\
2007 & 2007 & Single/Swath bathymetry & Louisiana Department of Natural Resources, 2013 \\
2014 & 2014 & Single/Swath bathymetry & DeWitt and others, 2016 \\
\hline
\end{tabular}

${ }^{1}$ Shoreline polygons used in this study from Terrano and others (2015).

${ }^{2}$ Digitized from U.S. Coast and Geodetic Survey Hydrographic Survey Smooth Sheets (Miner and others, 2009).

\section{Description of Study Area}

Breton Island is the final remnant of a transgressive island arc that formed during abandonment of a subdelta lobe of the St. Bernard delta complex and is one of the oldest barrier islands in Louisiana (Penland and others, 1988). In the literature Breton Island is considered to be the southernmost extension of the Chandeleur Island chain that began developing about 2,500 years before present (ybp), fol- 
lowing the avulsion of the La Loutre subdelta lobe (Frazier, 1967; Penland and others 1988; Rogers and others, 2009). However, its longitudinal position landward of the Chandeleur Island chain and its proximity to the terminal end of the Terre aux Boeufs subdelta lobe (Frazier, 1967; Rogers and others, 2009) suggest that the island may have formed earlier than the Chandeleur Islands, about 3,500 ybp. Following abandonment of the subdelta lobes, dewatering and compaction of the underlying sediments led to subsidence and flooding of the headland marsh, detaching and isolating the island from the mainland (Penland and others, 1988).

In the flooding stage of barrier island evolution, sandy sediments necessary to maintain island elevation and position are largely restricted to alongshore transport through littoral processes. In the southern Chandeleur Islands, the prevailing net longshore transport of sediment is from the north to the south (Ellis and Stone, 2006). Because of a similar wave climate and protection from the modern Mississippi River Delta to the south (fig. 1), it is believed that similar littoral processes exist at Breton Island. Sediment supply is limited, however, and as a result, Breton Island is losing elevation and island area. The island is also retreating landward through rollover produced by overwash of the sandy shoreface to the back barrier during storm impact. Presently, a limited area of marsh deposits located at the core of the island resists erosion from wave action and provides a locus for sand retention.

In 1968, the MRGO shipping channel was completed to reduce shipping distance between the Gulf of Mexico and the Port of New Orleans. This 152-meter (m)-wide, 11-m-deep shipping channel was dredged immediately to the north of Breton Island (fig. 1) adjacent to a natural tidal channel between the Breton and Gosier platforms. Over the past half-century, Breton Island began to experience rapid erosion rates (Terrano and others, 2016a), likely attributed to storm impact (for example, Hurricane Camille in 1969), the removal of sediment from the system through maintenance dredging and disposal, and overall reduction in littoral sediment transport across the MRGO (Lavoie, 2009). Shoreline change analysis from Terrano and others (2016a) measured a 51-percent reduction in island area before and after construction (1950-1978). In April 1996, Louisiana State University initiated the Beneficial Use Monitoring Program, which was designed to create a feeder berm using sand dredged from the MRGO to replenish the sand being lost on Breton Island. Between 1993 and 2006, four sand placements occurred adjacent to the island (Penland and others, 1997). Following Hurricane Katrina in 2005, the MRGO was decommissioned, and maintenance dredging of the channel has ceased. This study records the subsequent infilling of the channel through natural processes. The only other human development on the uninhabited island is oil industry infrastructure (bulkhead) on the center of the island and a rock weir extending along the Sound-side at the north end of the island.

\section{Breton Island Shoreline Change and Storm History}

A high-resolution shoreline change analysis was completed in Terrano and others (2016a), which will be summarized here. The study acquired 14 shoreline datasets that spanned from 1869 to 2014 (Terrano and others, 2015). These shorelines were digitized from U.S. Coast and Geodetic Survey topographic sheets (T-Sheets) (1869-1950), USGS and U.S. Department of Agriculture aerial imagery (1983-2012), and USGS lidar surveys (2001-2014). For a complete description on how these data were processed, see Terrano and others (2016a). The island has segmented and lost all of its southern half, and it has retreated landward approximately $846 \mathrm{~m}$ over the past 145 years. Only a small part of the northern end of the island has remained, stabilized by mangrove and marsh vegetation and underlying marsh substrate (fig. 3). This area was the only remnant to remain following Hurricanes Ivan and Katrina, which completely submerged the island with storm surge and reduced island area 64 percent (from 


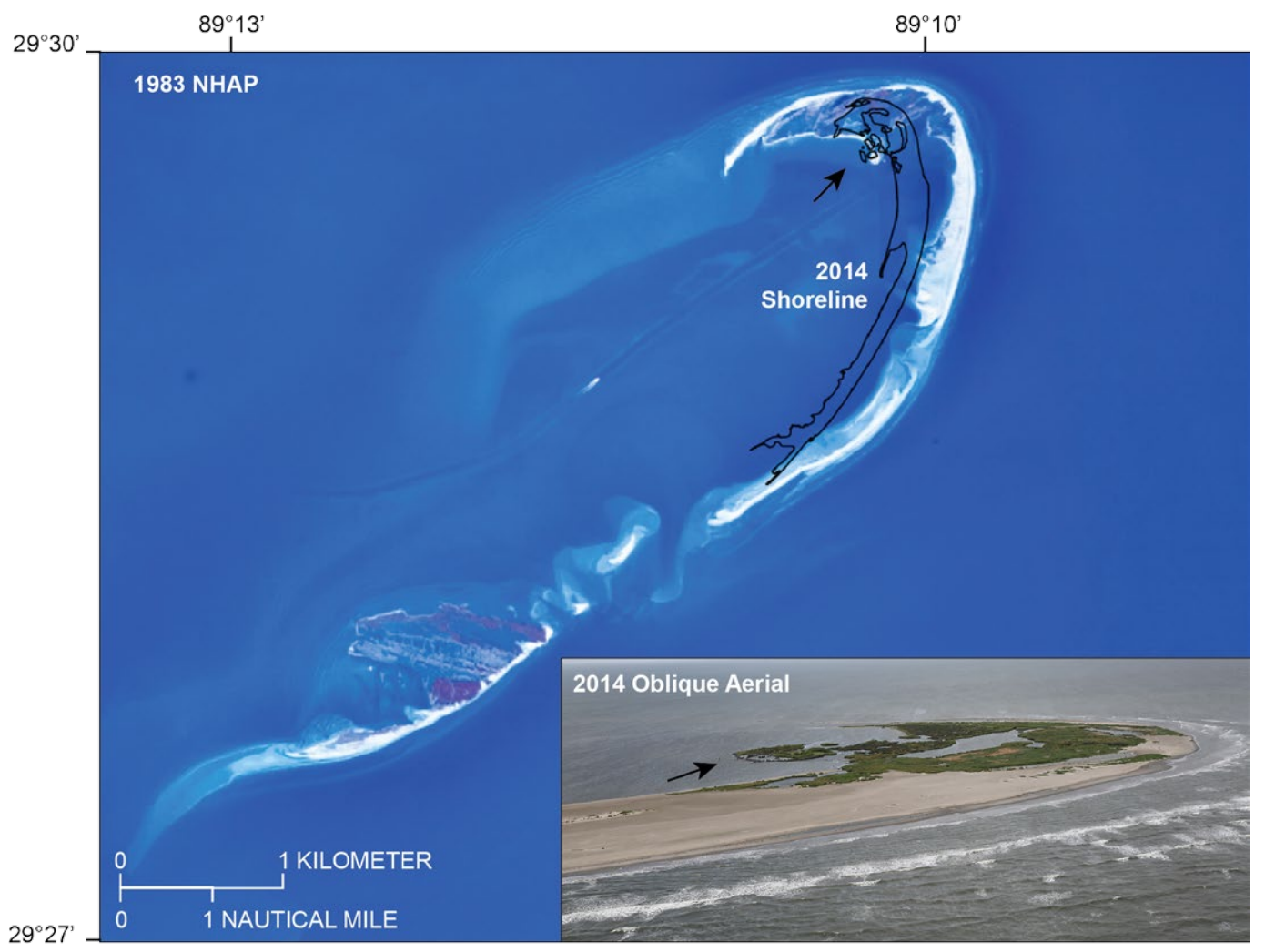

Figure 3. Photograph from the U.S. Geological Survey National High Altitude Photography (NHAP) program showing Breton Island in 1983, with the 2014 shoreline (derived from lidar) overlain as a black line. The southern half of the island is presently submerged. Inset is an oblique aerial photograph of the northernmost part of the island, where the only vegetation exists. The black arrow points to the same location in the photograph and the 2014 shoreline. Oblique aerial photography from Morgan (2015) and shoreline from Terrano and others (2015).

0.52 to 0.18 square kilometer $\left[\mathrm{km}^{2}\right]$ ). Following Hurricane Katrina, Breton Island showed a slow rate of land loss until 2008, after which the island began to recover, aided by the absence of severe storms since the storm. The unsubmerged part of the island has increased from its smallest area of $0.14 \mathrm{~km}^{2}$ in 2007 to $0.43 \mathrm{~km}^{2}$ in 2014 .

Although Hurricane Katrina was the most significant storm to impact Breton Island in terms of storm surge and intensity, the island has suffered numerous significant erosional events (Hurricane Andrew, 1992; Hurricane Opal, 1995; Hurricane Georges, 1998; Hurricane Isidore, 2002; and Hurricane Ivan, 2004; fig. 4). The relative impacts of the storms have been scored by measurements of various physical parameters taken when the storms were at their closest approach to the island. Distance and position relative to island, heading, central pressure, wind speed, direction, and wave heights were measured at National Oceanic and Atmospheric Administration buoys near the island. Figure 4 also shows placement events, where sediment dredged from the MRGO shipping channel was placed adjacent to Breton Island to allow littoral transport of sediment to the island shoreface.

\section{Methods}

A summary of the legacy data is described below, followed by a description of the data collection, processing, and grid generation of the 2014 dataset. 


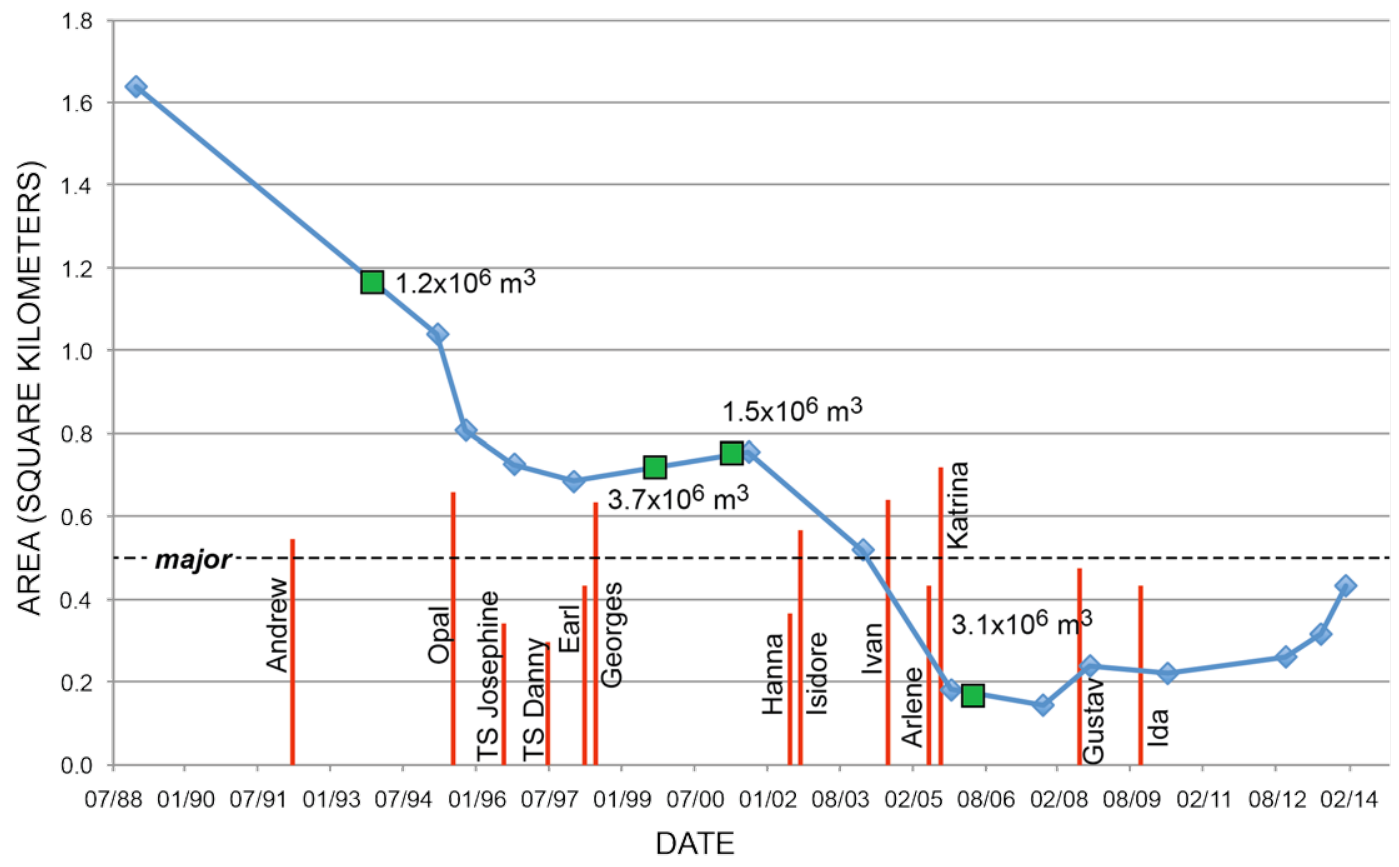

Figure 4. Graph showing change in island area (blue line) between 1988 and 2014 with blue diamonds denoting island area measurements from Terrano and others (2016a). Red lines mark dates of storm impacts to the island during the time period. Height of lines represent a ranking of relative storm impact during its closest 6-hour approach to the island based on the storm's central pressure, wind speed, wave height, distance, heading, and bearing. Green squares annotate Mississippi River-Gulf Outlet dredge spoil placement events (with estimated amounts of sediment placed). Dredge spoil was placed in shallow water adjacent to the island to assist in island recovery through littoral transport during normal wave conditions. [ $\mathrm{m}^{3}$, cubic meters]

\section{Historical Data}

This study builds upon the Louisiana Coastal Protection and Restoration Authority Barrier Island Comprehensive Monitoring (BICM) project, which compared bathymetry around Breton Island during 1869, 1920, and 2007 (Miner and others, 2009; Kindinger and others, 2013). The digital elevation models (DEMs) developed through the BICM project are used in this study; complete information on their development can be found in Miner and others (2009) and List and others (1994). Land elevations in the DEMs are assigned a uniform elevation of $0.5 \mathrm{~m}$ (Miner and others, 2009). The DEMs were reported in the Universal Transverse Mercator zone 15, North American Vertical Datum of 1988 (UTM zone 15, NAVD 88). For this study, the DEMs were converted to UTM zone 16, and their spatial extents were correlated to the 2014 DEM using QGIS, version 2, and Generic Mapping Tools (GMT), version 5, software packages.

\section{Data Collection and Processing}

The 2014 bathymetric data collected around Breton Island and Gosier Shoals were acquired in July and August 2014. A complete description of acquisition and processing, including system specifications, can be found in DeWitt and others (2016) and will be summarized here. The survey area encompasses approximately $356 \mathrm{~km}^{2}$ and extends from the shorelines of Breton Island and Gosier Shoals approximately 5 kilometers $(\mathrm{km})$ west into Breton Sound and approximately $10 \mathrm{~km}$ east into the Gulf of Mexico (fig. 5). Slightly more than 1,558 line-km of single-beam bathymetry (SBB) and 991 line-km of interferometric-swath bathymetry (IFB) were collected. Survey platforms included 9-m 


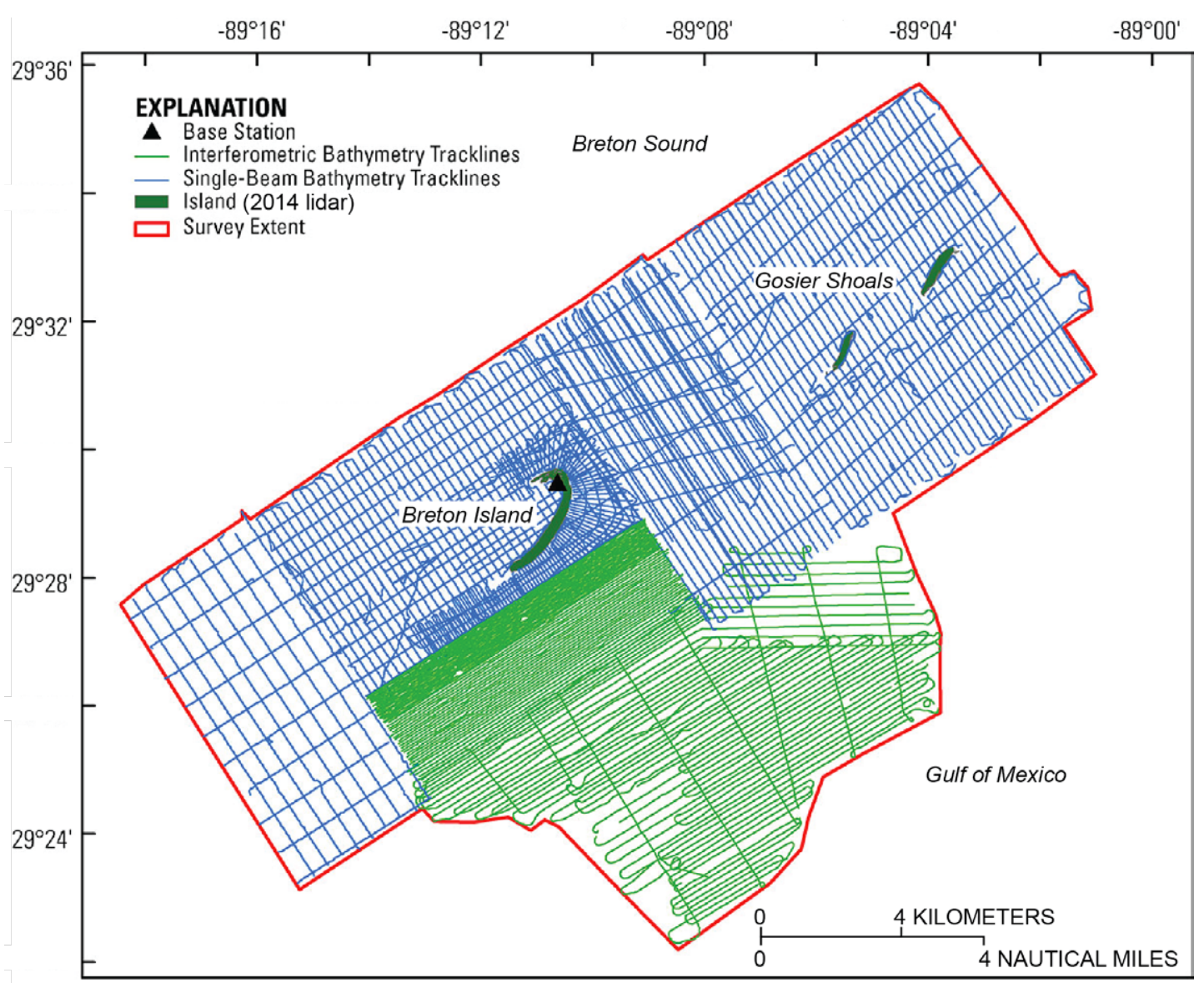

Figure 5. Trackline map showing survey extent and coverage of single-beam and interferometric-swath bathymetric systems around Breton Island, Gosier Shoals, and offshore. The historical digital elevation models (DEMs) were clipped to this survey extent. Figure modified from DeWitt and others (2016).

and 5-m outboard vessels, a personal watercraft for shallow water work, and the 29-m research vessel (RV) Tommy Munro for deep water offshore. Water depths ranged from 0.4 to $10.6 \mathrm{~m}$. Navigation was recorded by using differential global positioning system (DGPS) receivers corrected to measurements from a global positioning system (GPS) base station installed over a USGS benchmark on Breton Island (fig. 5). Offshore navigation was corrected by using the Marinestar HP differential navigation service. Sound velocity through the water column was acquired by using sound velocity profilers (SVPs) mounted on the IFB system and through periodic SVP casts by all vessels. Internal motion referencing systems measured heave, pitch, and roll on the RV Tommy Munro and the two outboard vessels. The personal watercraft compensated for motion by using a very high GPS sampling rate $(0.1$ second, compared to 1.0 second for the larger vessels) and a narrow (4 degree) transducer beam angle. Single-beam bathymetry was collected at 50 -millisecond intervals by using a 200 -kilohertz $(\mathrm{kHz})$ transducer. IFB was collected by using a 468-kHz system.

All bathymetric and navigation data were processed by using the CARIS geospatial software package. The final product was transformed to the North American Datum of 1983 (NAD 83) UTM zone 16N, and NAVD 88 (GEOID09) horizontal and vertical datums (DeWitt and others, 2016) prior to creating the 2014 DEM.

In addition to the acoustic bathymetric data, topo/bathymetric data were collected at Breton Island and Gosier Shoals by using airborne lidar. The data were collected by the Quantum Spatial 
Company in December 2013, using a Riegl VQ-280-G airborne laser scanner acquiring at a target point density of 4 points per square meter or greater. Survey altitude was $600 \mathrm{~m}$ with a laser pulse rate of 284 $\mathrm{kHz}$ and a laser spot diameter of 60 centimeters $(\mathrm{cm})$. The same DGPS base station used for the acoustic bathymetry surveys was deployed on the island during flight, and ground control data to verify accuracy were acquired by using GPS rapid static measurements. The differences between ground control elevations and lidar elevations ranged from 0.009 to $0.167 \mathrm{~m}$, with an average of $0.071 \mathrm{~m}$ at 15 bare earth, vegetated, and submerged sites. The lidar data were reported in NAD 83 UTM Zone 16, NAVD 88 (GEOID12A) and were converted to GEOID09 for this study. For complete information on lidar data acquisition and processing, see Terrano and others (2016b).

\section{Final 2014 DEM}

The 2014 DEM was created by combining the bathymetric soundings and lidar elevations from the individual platforms. A running mean of $2 \mathrm{~m}$ was applied to each dataset by using the GMT blockmean filter to avoid aliasing short wavelengths. Because of the dense data volume within the shallowwater data collected by the personal watercraft and overlapping topo/bathymetric lidar survey, the two data files were merged and a blockmean filter was applied to the merged data. The merged data were first sorted by geographic position so that the blockmean filter would prioritize by position rather than by acquisition platform. The resulting data file was then gridded to 50-m grid cells by using the GMT surface algorithm with a search radius of $200 \mathrm{~m}$ to initialize the grid and a tension filter of 0.03 to suppress spurious oscillations. A grid mask generated from a polygon digitized around the survey area was applied to the resulting grid to exclude areas of no data using the GMT grdmask and grdmath functions. Statistics for the datasets listed by platform, along with the root-mean-square error for the resulting grid, are reported in table 2 .

\section{Bathymetric-Change Analysis}

The mathematical difference between two DEMs provides the change in elevation values between the two time periods. The DEMs of the historical datasets $(1869,1920$, and 2007) were clipped to the extents of the 2014 DEM. The 2007 survey did not extend as far offshore as the 2014 survey, and that portion of the 2007 grid was assigned null values. Portions of the 1920 DEM within the 2014 survey area did not contain sufficient soundings, and those areas were assigned null values. All of the DEMs were sampled to same grid interval of the historical DEMs $(100 \mathrm{~m})$. It should be noted that the

Table 2. Bathymetric dataset statistics by survey platform used to create the Breton 2014 DEM.

[Root-mean-square error (RMSE) represents how well the 2014 DEM represents the data. Table modified from DeWitt and others (2016). Depths are relative to North American Vertical Datum of 1988. Abbreviations: NAD 83, North American Datum of 1983; UTM, Universal Transverse Mercator; m, meter; RV, research vessel; IFB, interferometric bathymetry; SBB, single-beam bathymetry; TB, topographic/bathymetric light detection and ranging (lidar)]

\begin{tabular}{|c|c|c|c|c|c|c|}
\hline \multirow[t]{2}{*}{ Platform } & \multirow{2}{*}{$\begin{array}{l}\text { Data } \\
\text { type }\end{array}$} & \multirow{2}{*}{$\begin{array}{l}\text { Number of } \\
\text { data points }\end{array}$} & \multirow{2}{*}{$\begin{array}{c}\text { X/Y-Extents } \\
\text { NAD } 83 \text { UTM 16N }\end{array}$} & \multicolumn{2}{|c|}{ Z-Measured depth } & \multirow{2}{*}{$\begin{array}{c}\text { RMSE } \\
\mathrm{m}\end{array}$} \\
\hline & & & & Min. (m) & $\operatorname{Max} .(m)$ & \\
\hline RV Sallenger & IFB & 671,459 & $283665 / 293290 / 3256000 / 3263570$ & -8.35 & -2.44 & 0.03 \\
\hline RV Jabba Jaw & SBB & 466,235 & $277310 / 304240 / 3253770 / 3275640$ & -10.65 & -1.38 & 0.06 \\
\hline Personal watercraft & SBB & 436,813 & $281715 / 302838 / 3258501 / 3275640$ & -10.44 & -0.62 & 0.06 \\
\hline RV Tommy Munro & IFB & $1,013,072$ & $285000 / 299610 / 3251855 / 3262865$ & -10.34 & -3.69 & 0.03 \\
\hline $\begin{array}{l}\text { Topographic/ } \\
\text { bathymetric lidar }\end{array}$ & TB & 321,301 & $285382 / 301321 / 3260594 / 3271639$ & -2.57 & 2.08 & 0.06 \\
\hline
\end{tabular}


sampling densities (for example, trackline spacing) between surveys are highly variable and inherently increase error in this type of analysis. See Miner and others (2009) for maps showing trackline spacing of the pre-2014 surveys.

Once the four DEMs were sampled to the same geographic extents and vertical datums, the bathymetric change between each period was determined by subtracting the older period from the more recent period by using the grdmath function in GMT to provide an isopach grid of erosion (negative values) and accretion (positive values). To better delineate areas of erosion and accretion, isopach differences between $-0.25 \mathrm{~m}$ and $+0.25 \mathrm{~m}$ were considered beyond the error of analysis and set to zero. The time periods chosen for analysis were 1869-2014, 1869-1920, 1920-2014, and 2007-2014. Bathymetric change between time periods can also be directly compared along 2-dimensional transects across the DEMs with stacked results in profile to show relative elevations. These profiles were extracted from the DEMs by using the transit plug-in in QGIS.

Spatial and volume change between the time periods was determined by using the grdvolume function in GMT, which calculates area, volume, and volume per unit area for a provided polygon within a DEM. The polygon delineates areas of interest within the study area such as geomorphic features. For this analysis, the Breton Island platform, the Gosier Shoals platform, the MRGO corridor, and an offshore shoal feature were selected as important geomorphic features that have experienced significant change over the study period. The areas of interest were outlined from the 2014 DEM and applied to the remaining years.

\section{Sediment Composition}

Grain size and sorting of sediments collected from within the study area are briefly introduced in this report with respect to bathymetry. Island, shoal, and seafloor sediments were collected by using 1-m hand augers, and ponar grabs, and by vibracoring. Sample locations were determined by using DGPS. Subsamples of the ponar grabs and the top intervals of the augers and vibracores were selected to represent the seafloor sediment characteristics. Grain size and sorting statistics of these subsamples were analyzed by using a Coulter LS200 particle-size analyzer.

\section{Results and Discussion}

The DEMs for 1869, 1920s, 2007, and 2014 are shown in figures 6-9, respectively. Shorelines for Breton Island and Gosier Shoals (the shoals are only emergent in 2014) have been overlain on the maps. The DEMs were clipped to the extent of the 2014 survey, and certain areas of the 1920s and 2007 grids were clipped because of insufficient or no data (gray background). The 1869 (fig. 6) and 1920s (fig. 7) maps pre-date the MRGO and show two distinct tidal channels between the Breton and Gosier platforms. Evident in all years is shoaling offshore of the inlets. The most recent coverage (fig. 9) shows a shoreline recovery of Breton Island and emergence of Gosier Shoals in the years following Hurricane Katrina.

The erosion/accretion isopach maps for the time periods 1869-2014, 1869-1920s, 1920s-2014, and 2007-2014 are shown in figures 10-13. These time periods represent long-term change, pre-MRGO, dredging of the MRGO/Hurricane Katrina impact, and post-Hurricane Katrina recovery, respectively, and will be discussed in the context of these periods and events. 


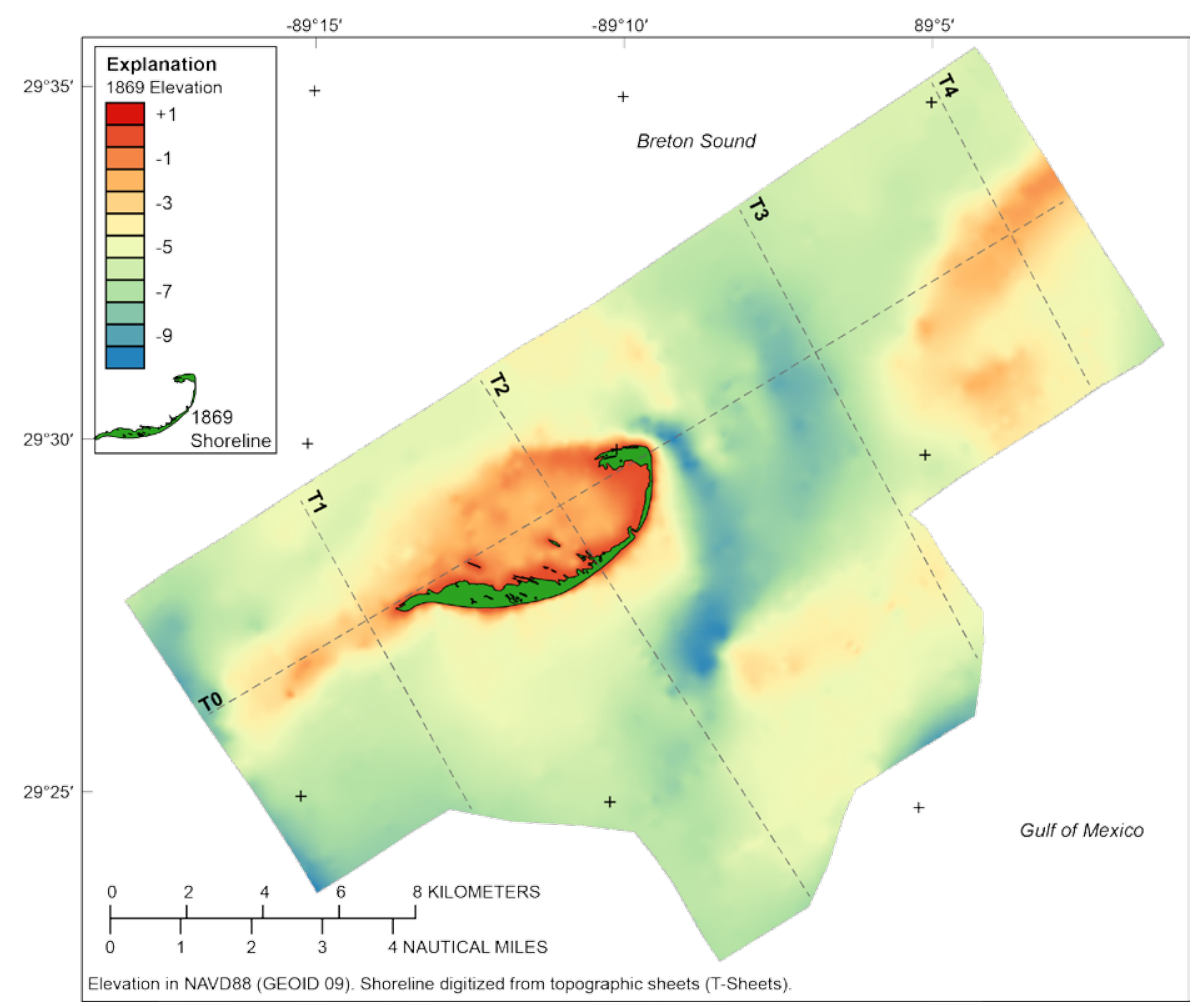

Figure 6. Digital elevation model (DEM) generated from 1869 hydrographic sheets (H-sheets) (see table 1 for source). Overlain onto the DEM are transect locations (dashed lines, T0-T4) used to represent vertical change profiles between time periods.

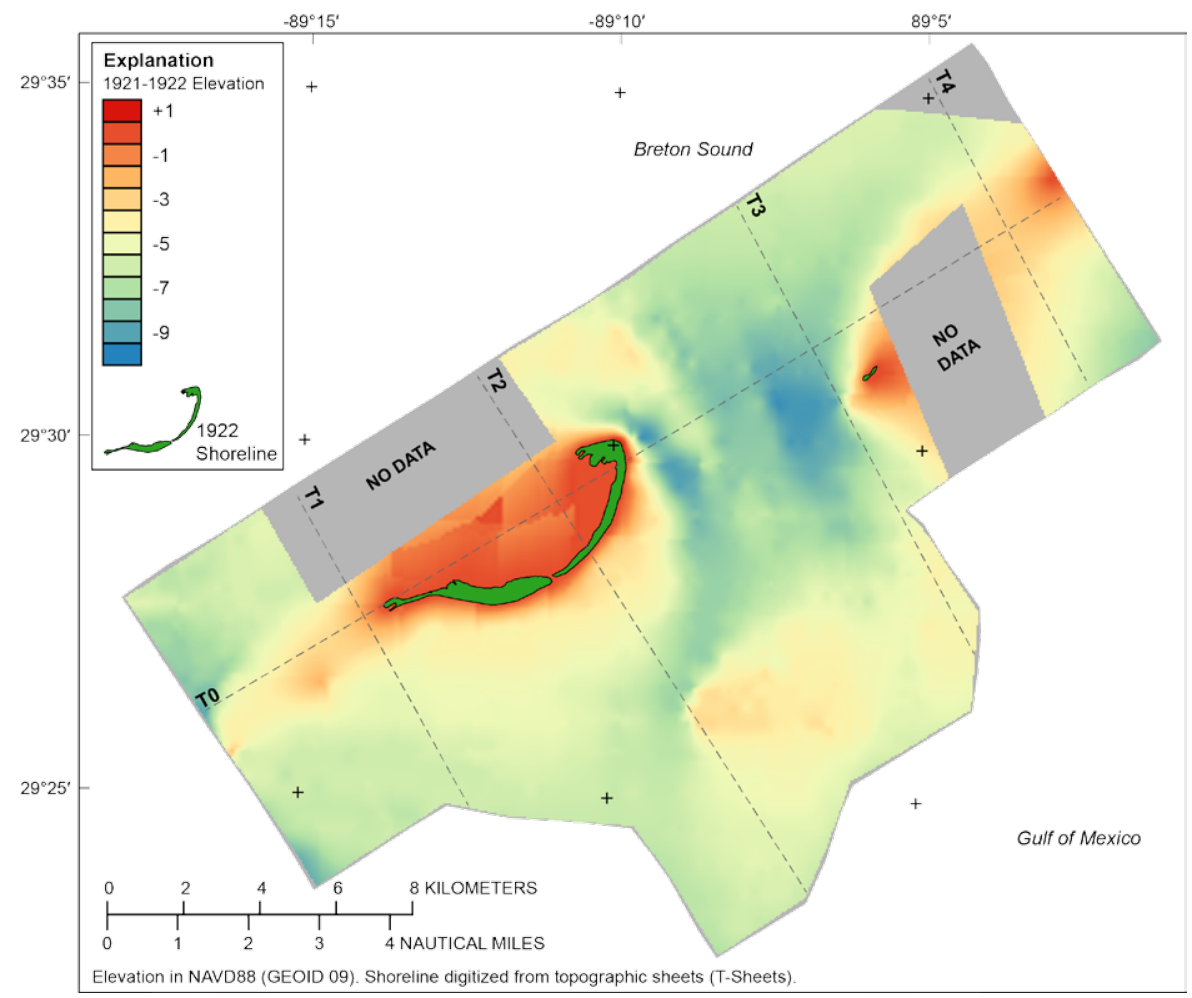

Figure 7. Digital elevation model (DEM) generated from 1921-1922 hydrographic sheets (H-sheets) (see table 1 for source). Overlain onto the DEM are transect locations (dashed lines, T0-T4) used to represent vertical change profiles between time periods. Areas where no trackline data exist were excluded from the DEM. 


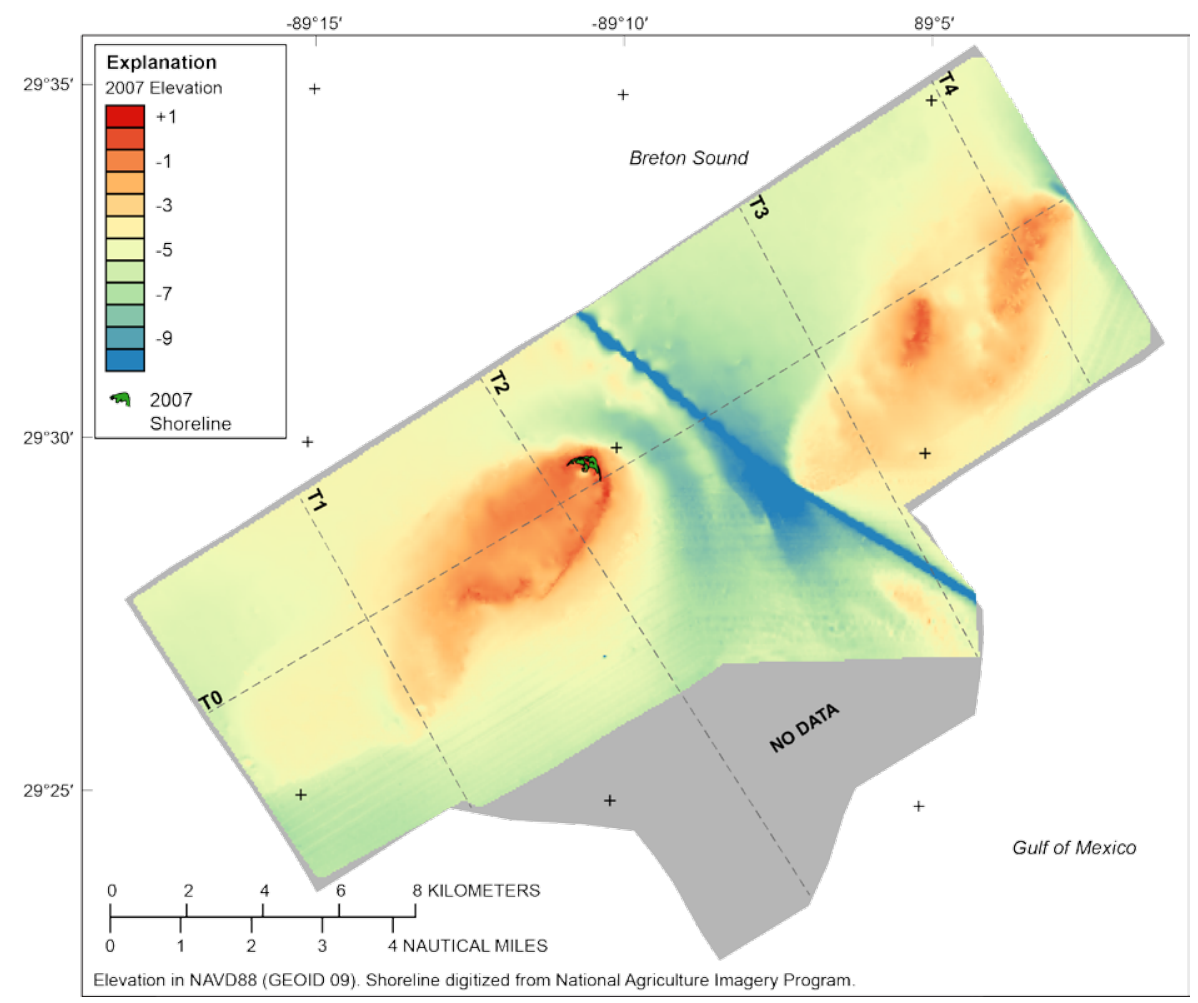

Figure 8. Digital elevation model (DEM) generated from 2007 bathymetric data (see table 1 for source). Overlain onto the DEM are transect locations (dashed lines, T0-T4) used to represent vertical change profiles between time periods. Areas where no trackline data exist were excluded from the DEM.

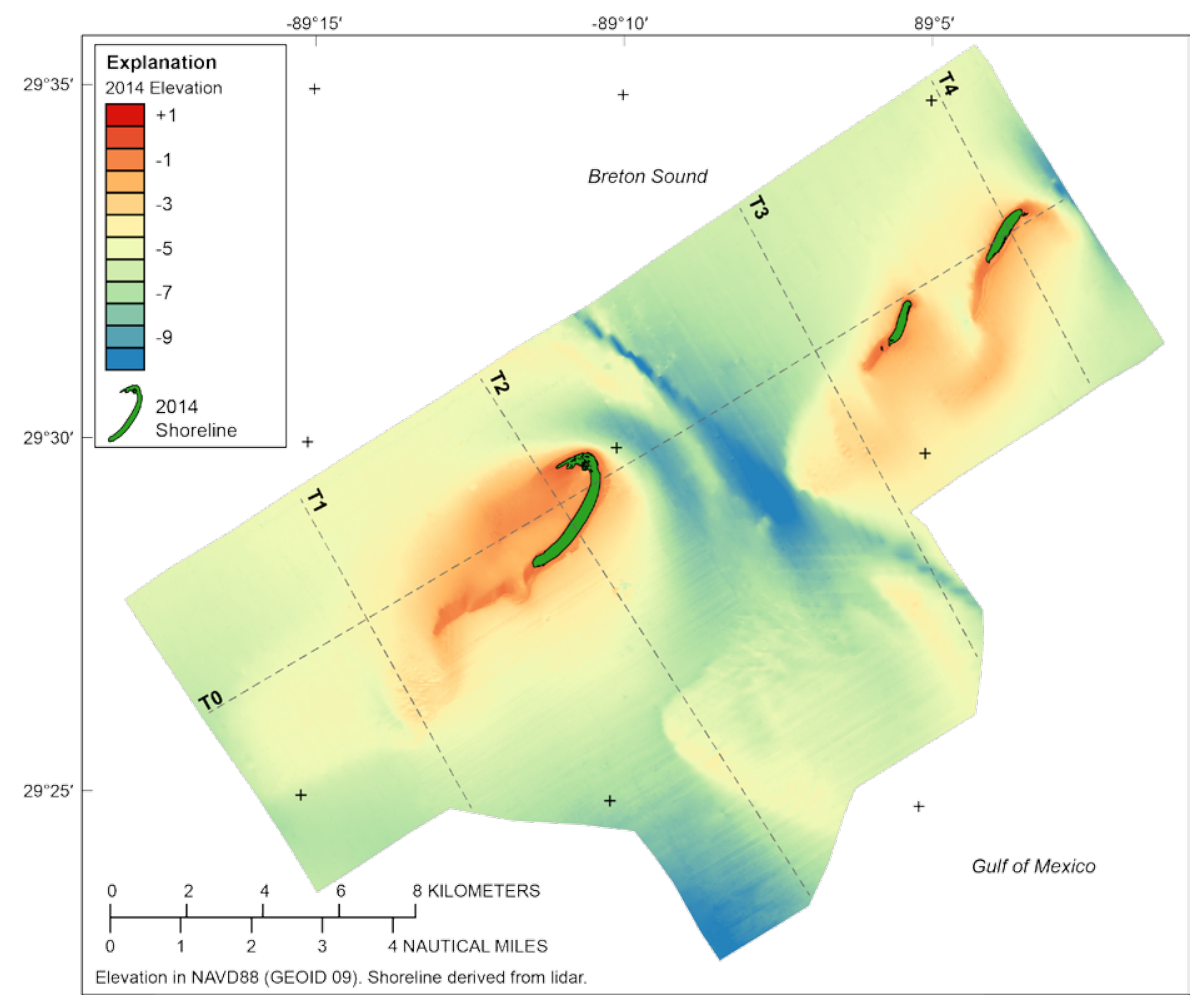

Figure 9. Digital elevation model (DEM) generated from 2014 bathymetric data. Overlain onto the DEM are transect locations (dashed lines, T0-T4) used to represent vertical change profiles between time periods. 


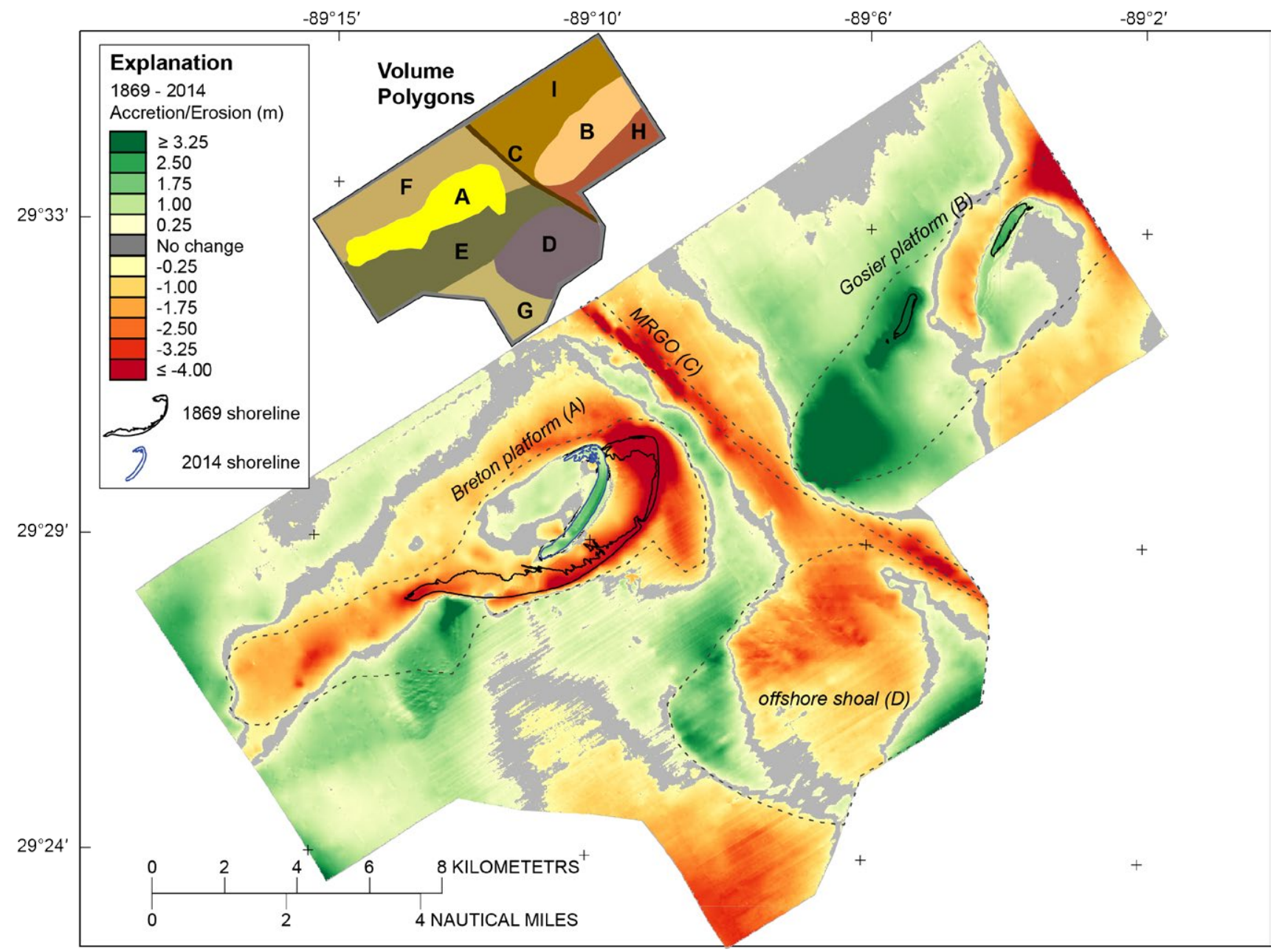

Figure 10. Map showing long-term elevation change determined by calculating the difference in digital elevation models (DEMs) between 1869 and 2014, considered to be accretion (positive change) and erosion (negative change) over the time period. Elevation differences within $+/-0.25$ meter $(m)$ are assumed to have no change. Overlain onto the DEM are locations of key features (labeled polygons A-D) identified in the 2014 DEM and used to generate volume change statistics. Remaining areas are divided as follows (see inset map for locations): E, Breton Gulf; F, Breton Sound; G, Offshore gulf; H, Gosier Gulf; and I, Gosier Sound. 


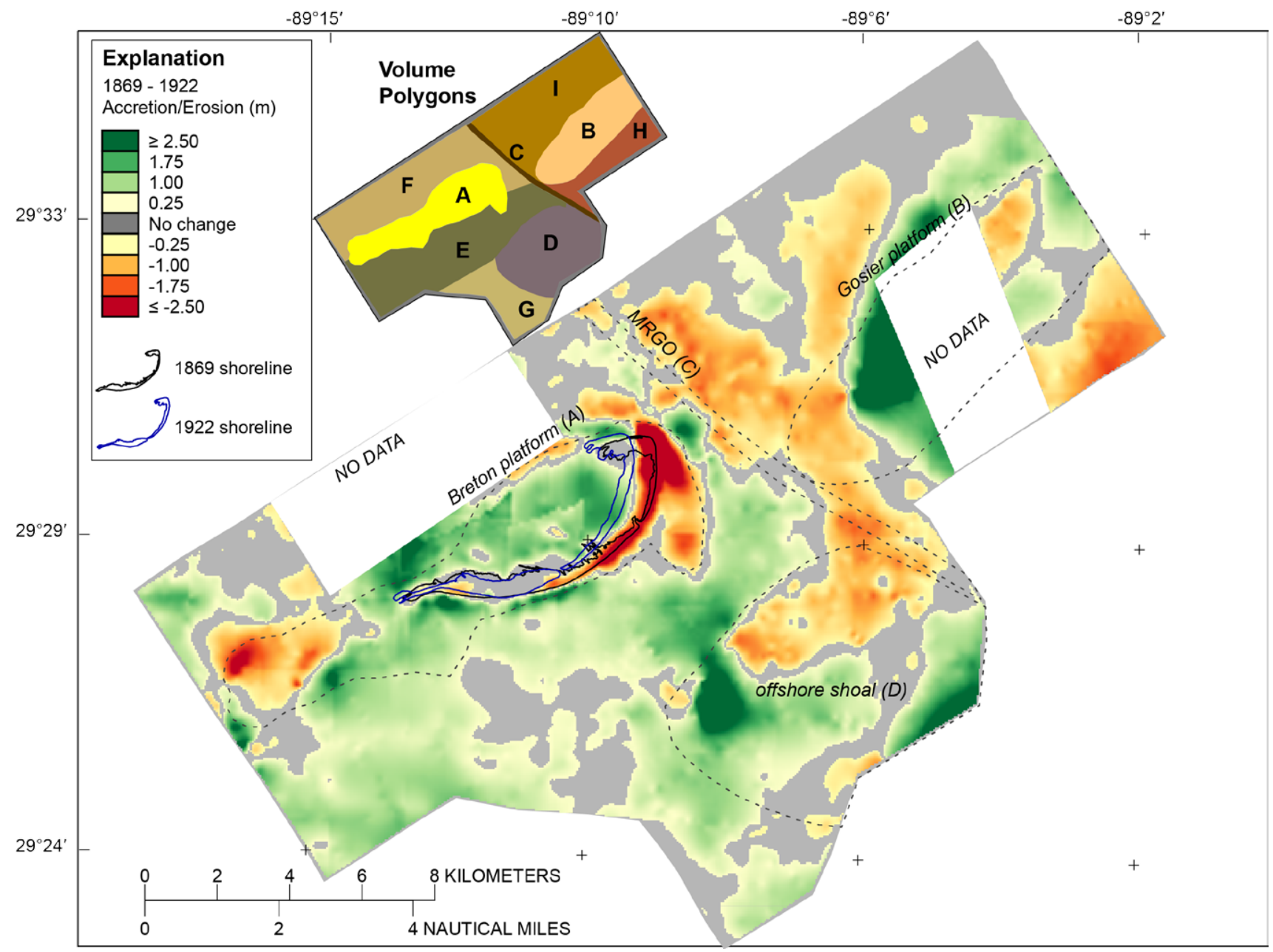

Figure 11. Map showing pre-Mississippi River-Gulf Outlet (MRGO) elevation change determined by calculating the difference in digital elevation models (DEMs) between 1869 and 1920, considered to be accretion (positive change) and erosion (negative change) over the time period. Elevation differences within $+/-0.25$ meter $(\mathrm{m})$ are assumed to have no change. Overlain onto the DEM are locations of key features (labeled polygons $A-D$ ) identified in the 2014 DEM and used to generate volume change statistics. Although the time period predates MRGO construction, the polygon is included for reference. Remaining areas are divided as follows (see inset map for locations): E, Breton Gulf; F, Breton Sound; G, Offshore gulf; H, Gosier Gulf; and I, Gosier Sound. The 1922 survey contains areas with no data, which reduces the accretion/erosion volume estimates for those areas and cannot be compared to other time periods. 


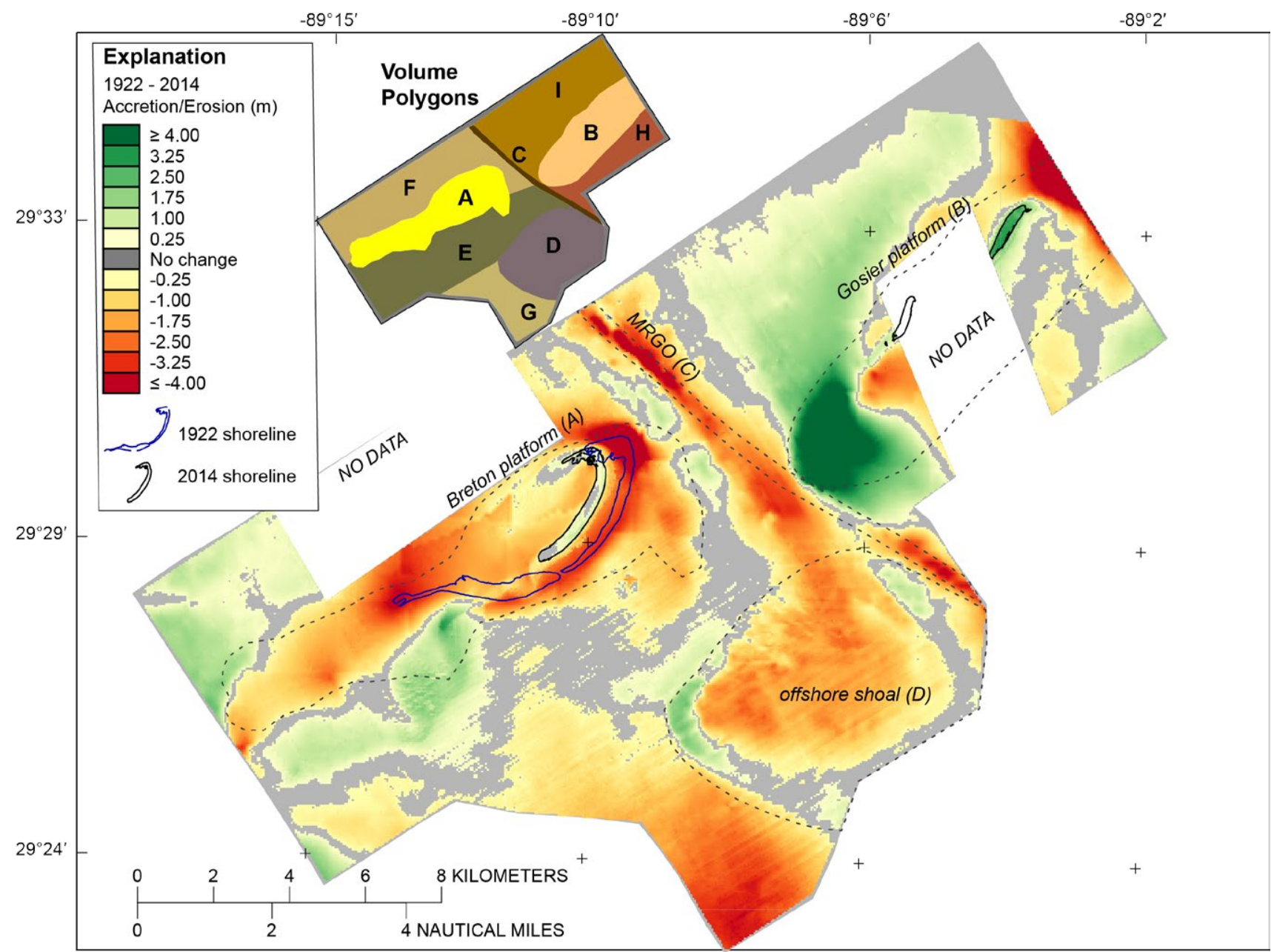

Figure 12. Pre/post-Mississippi River-Gulf Outlet (MRGO) and Hurricane Katrina impact determined by calculating the difference in digital elevation models (DEMs) between 1922 and 2014, considered to be accretion (positive change) and erosion (negative change) over the time period. Elevation differences within $+/-0.25$ meter $(\mathrm{m}$ ) are assumed to have no change. Overlain onto the DEM are locations of key features (labeled polygons A-D) identified in the 2014 DEM and used to generate volume change statistics. Remaining areas are divided as follows (see inset map for locations): E, Breton Gulf; F, Breton Sound; G, Offshore gulf; H, Gosier Gulf; and I, Gosier Sound. The 1922 survey contains areas with no data, which reduces the accretion/erosion volume estimates for those areas and cannot be compared to other time periods. 


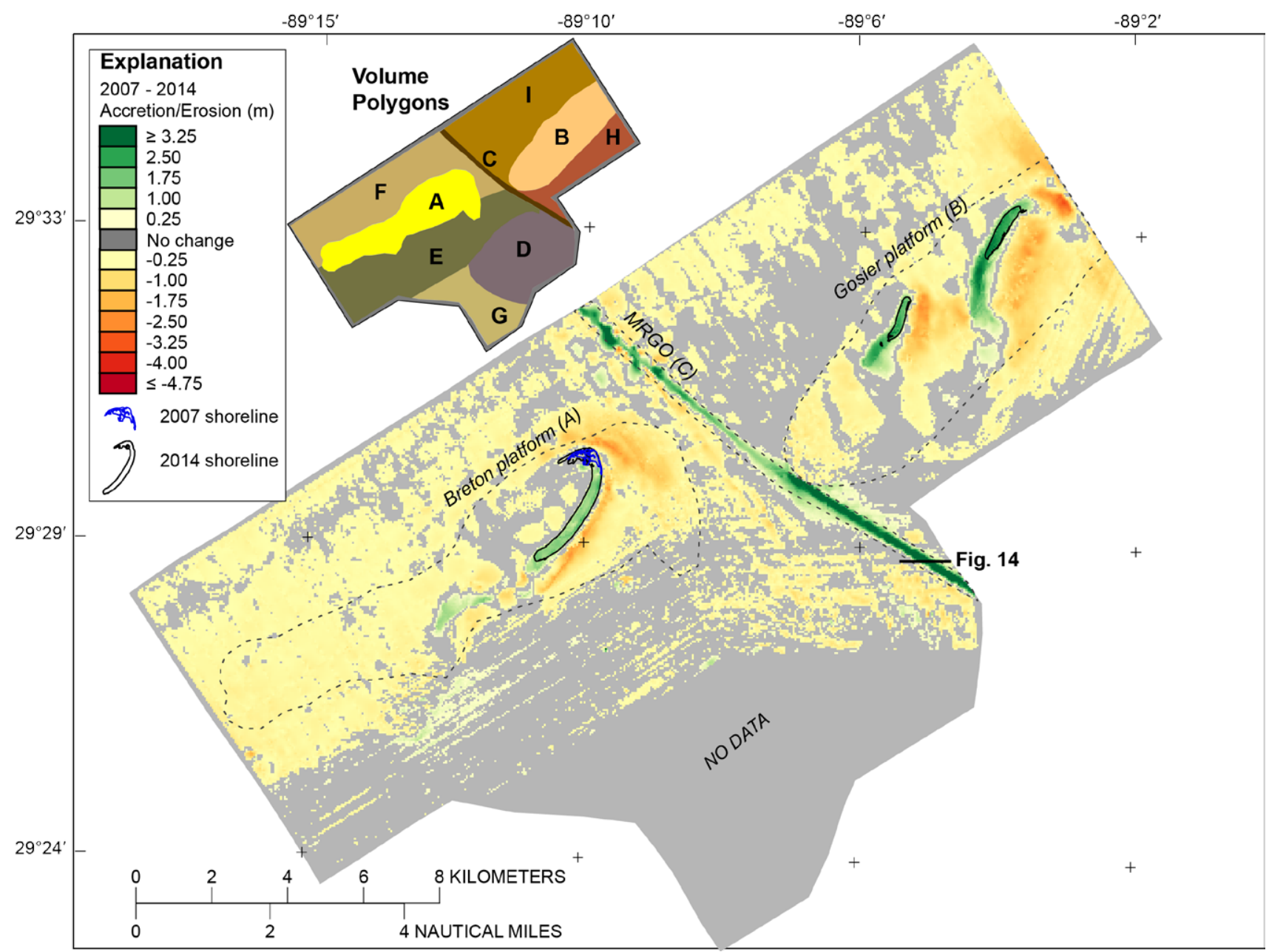

Figure 13. Post-Hurricane Katrina recovery determined by calculating the difference in digital elevation models (DEMs) between 2007 and 2014 , considered to be accretion (positive change) and erosion (negative change) over the time period. Elevation differences within $+/-0.25$ meter $(\mathrm{m})$ are assumed to have no change. Overlain onto the DEM are locations of key features (labeled polygons A-C) identified in the 2014 DEM and used to generate volume change statistics. Remaining areas are divided as follows (see inset map for locations): E, Breton Gulf; $F$, Breton Sound; G, Offshore gulf; H, Gosier Gulf; and I, Gosier Sound. The 2007 survey contains no data offshore, so volume estimate for the offshore shoal feature for this time period was not calculated.

\section{Long-Term Change (1869-2014)}

The long-term change (fig. 10) shows dramatic rollover of Breton Island, with more than $1 \mathrm{~km}$ of landward migration in some places, and 4-8 $\mathrm{m}$ of vertical loss to the foreshore. Erosion occurred across the length of the platform, with accretion along the platform margins. Approximately $42.01 \times 10^{6}$ cubic meters $\left(\mathrm{m}^{3}\right)$ of sediment was removed from the Breton platform during this time period (table 3 ). The former southern tip of Breton Island submerged and migrated offshore, raising the elevation there by $3 \mathrm{~m}$ (fig. 10). On the Gosier platform, up to $4 \mathrm{~m}$ of accretion occurred on the terminal end, and the shoals themselves gained elevation and became emergent. Unlike the Breton platform, the Gosier platform gained $33.84 \times 10^{6} \mathrm{~m}^{3}$ of sediment (table 3). Excavation of the MRGO is clearly evident with a sediment deficit of $12.95 \times 10^{6} \mathrm{~m}^{3}$. The offshore shoal deflated over the past century, losing $17.13 \times 10^{6} \mathrm{~m}^{3}$ of sediment, migrating to the flanks of the shoal up to $3 \mathrm{~m}$ thick. The entire study area experienced a net loss of sediment, although about 40 percent of sediment loss was through the excavation of the MRGO (table 3 ). 
Table 3. Accretion and erosion volumes, changes, and rates of change during the four study time periods for the four target features (Breton platform, Gosier platform, MRGO, and offshore shoal) and other areas within the Breton National Wildlife Refuge, Louisiana, study area.

[MRGO, Mississippi River-Gulf Outlet; $\mathrm{m}^{3}$, cubic meters; $\mathrm{m}^{3} / \mathrm{yr}$, cubic meters per year]

\begin{tabular}{|c|c|c|c|c|c|c|}
\hline Time period & $\begin{array}{c}\text { Interval } \\
\text { years }\end{array}$ & Feature/ Area & $\begin{array}{c}\text { Accretion } \\
\left(10^{6} \mathrm{~m}^{3}\right)\end{array}$ & $\begin{array}{l}\text { Erosion } \\
\left(10^{6} \mathrm{~m}^{3}\right)\end{array}$ & $\begin{array}{l}\text { Change } \\
\left(10^{6} \mathrm{~m}^{3}\right)\end{array}$ & $\begin{array}{c}\text { Rate of change } \\
\left(10^{6} \mathrm{~m}^{3} / \mathrm{yr}\right)\end{array}$ \\
\hline \multirow[t]{9}{*}{ 1869-2014 } & 144 & Breton platform & 11.04 & 53.05 & -42.01 & -0.29 \\
\hline & & Gosier platform & 44.77 & 10.93 & 33.84 & 0.23 \\
\hline & & MRGO & 0.41 & 13.35 & -12.95 & -0.09 \\
\hline & & Offshore shoal & 14.56 & 31.69 & -17.13 & -0.12 \\
\hline & & Breton Gulf & 37.89 & 8.57 & 29.32 & 0.20 \\
\hline & & Breton Sound & 17.47 & 18.97 & -1.51 & -0.01 \\
\hline & & Offshore Gulf & 0.50 & 27.34 & -26.85 & -0.19 \\
\hline & & Gosier Gulf & 5.71 & 10.31 & -4.60 & -0.03 \\
\hline & & Gosier Sound & 25.48 & 14.07 & 11.41 & 0.08 \\
\hline \multirow[t]{9}{*}{ 1869-1920 } & 50 & Breton platform & 21.43 & 17.48 & 3.94 & 0.08 \\
\hline & & Gosier platform $^{1}$ & 17.30 & 5.13 & 12.17 & 0.24 \\
\hline & & MRGO & 0.17 & 2.14 & -1.97 & -0.04 \\
\hline & & Offshore shoal & 23.49 & 7.50 & 15.98 & 0.32 \\
\hline & & Breton Gulf & 35.86 & 1.06 & 34.80 & 0.70 \\
\hline & & Breton Sound ${ }^{1}$ & 10.70 & 3.43 & 7.28 & 0.15 \\
\hline & & Offshore Gulf & 8.41 & 0.13 & 8.28 & 0.17 \\
\hline & & Gosier Gulf & 1.03 & 7.20 & -6.17 & -0.12 \\
\hline & & Gosier Sound & 7.71 & 13.94 & -6.23 & -0.12 \\
\hline \multirow[t]{9}{*}{ 1920-2014 } & 94 & Breton platform & 4.35 & 50.18 & -45.83 & -0.49 \\
\hline & & Gosier platform ${ }^{1}$ & 28.01 & 12.82 & 15.19 & 0.16 \\
\hline & & MRGO & 0.63 & 11.42 & -10.78 & -0.11 \\
\hline & & Offshore shoal & 3.39 & 36.73 & -33.35 & -0.35 \\
\hline & & Breton Gulf & 10.51 & 17.08 & -6.57 & -0.07 \\
\hline & & Breton Sound $^{1}$ & 9.58 & 16.63 & -7.05 & -0.07 \\
\hline & & Offshore Gulf & 0.01 & 34.95 & -34.94 & -0.37 \\
\hline & & Gosier Gulf & 6.28 & 2.50 & 3.79 & 0.04 \\
\hline & & Gosier Sound & 25.51 & 9.61 & 15.90 & 0.17 \\
\hline \multirow[t]{7}{*}{ 2007-2014 } & 7 & Breton platform & 2.31 & 14.04 & -11.73 & -1.68 \\
\hline & & Gosier platform & 5.42 & 13.94 & -8.52 & -1.22 \\
\hline & & MRGO & 8.31 & 0.39 & 7.92 & 1.13 \\
\hline & & Breton Gulf & 1.48 & 17.72 & -16.24 & -2.32 \\
\hline & & Breton Sound & 0.42 & 19.18 & -18.76 & -2.68 \\
\hline & & Gosier Gulf & 0.55 & 12.15 & -11.60 & -1.66 \\
\hline & & Gosier Sound & 0.18 & 14.44 & -14.26 & -2.04 \\
\hline
\end{tabular}

${ }^{1}$ Data gaps occur in the 1920s coverage for these areas. Volumes cannot be compared to other time periods. 


\section{Pre-MRGO (1869-1920)}

The period prior to the construction of the MRGO was the only period of analysis where the net sediment volume for the study area increased. During this time period, the northern half of Breton Island rotated landward approximately $600 \mathrm{~m}$ while the southern half remained stationary (fig. 11). The former platform has eroded more than $2 \mathrm{~m}$, yet the Breton platform experienced a net gain of sediment (3.94 $\times 10^{6} \mathrm{~m}^{3}$; table 3$)$. The sediment eroded from the shoreface appears to have migrated both landward, contributing to the island platform west of the 1920s island position, and downdrift, offshore of the southern half of the island. Within the inlet between the Breton and Gosier platforms, approximately $2.14 \times 10^{6} \mathrm{~m}^{3}$ of sediment was eroded along the pre-MRGO tidal channel (table 3 ). The Gosier platform experienced a net gain of $12.17 \times 10^{6} \mathrm{~m}^{3}$, with up to $4 \mathrm{~m}$ of sediment accumulating at the southern terminal end of the Gosier platform (fig. 11). The deposition rate on the Gosier platform over this time period $\left(0.24 \times 10^{6}\right.$ cubic meters per year $\left.\left[\mathrm{m}^{3} / \mathrm{yr}\right]\right)$ is consistent with the long-term (1869-2014) deposition rate (table 3$)$, while the deposition rate on the Breton platform decreased from a surplus $\left(0.08 \mathrm{~m}^{3} / \mathrm{yr}\right)$ to a deficit over the long term $\left(-0.29 \mathrm{~m}^{3} / \mathrm{yr}\right.$ for $\left.1870-2014\right)$. This reversal suggests a detrimental influence from the excavation of the MRGO shipping channel in the 1960s and an inability of the island to recover from more intense storm impacts over the past half century (Terrano and others, 2016a). The offshore shoal experienced erosion along its northern flank and deposition along its western and southern flanks, with a net increase in sediment (table 3 ).

\section{MRGO and Hurricane Katrina (1920s-2014)}

Over this 94-year time span from 1920 to 2014, eight major (category 3 or greater) hurricanes passed within $150 \mathrm{~km}$ of Breton Island (Terrano and others, 2016a), and the study area as a whole experienced a larger net loss of sediment than during any other time period discussed in this report. The sediment volume deposited on the Breton platform over the previous half-century was removed 10 times over, at a rate of $-0.49 \mathrm{~m}^{3} / \mathrm{yr}$ (table 3 ). In contrast, the Gosier platform increased in volume by $12.82 \times 10^{6} \mathrm{~m}^{3}$ during this time period, again suggesting that the maintenance of the MRGO ship channel was inhibiting sediment deposition to Breton Island. Island rollover continued to occur at rates similar to those of the previous time period (fig. 12), although the southern part of the island has completely submerged. Aerial photo surveys of the island show that the final removal of the southern half of Breton Island occurred following Hurricanes Ivan and Katrina (Westphal, 2009). During the rollover process, sediment was eroded from the former shoreface and deposited at the present island location and offshore to the southwest. On the Gosier platform, more than $4 \mathrm{~m}$ of sediment was deposited on the terminal end of the platform (fig. 12). Most recently, the Gosier Shoals have emerged. The offshore shoal lost $33.35 \times 10^{6} \mathrm{~m}^{3}$ of sediment over this time period, probably during large storm events when wave base directly impacted the shoal. This sediment appears to have been completely removed from the shoal system because there is not a similar amount of sedimentation around the flanks of the shoal. The opposite is observed during the long-term (1869-2014) time period when sediment migrated from the shoal directly to the flanks (fig. 10). This time series captures the excavation of the MRGO, represented by a net loss of $10.78 \times 10^{6} \mathrm{~m}^{3}$.

\section{Post-Katrina Recovery (2007-2014)}

From 2007 to 2014, all areas of analysis experienced sediment loss, except for the MRGO polygon. Because the offshore shoal and offshore Gulf have no coverage from the 2007 DEM, these 
areas are not included in this analysis. Overall, more sediment was lost from the Breton platform than deposited, but Breton Island shows some recovery of its southern shoreline (fig. 13). It is clear in the change map that sediment for this recovery is derived from immediately offshore and to the north of the island, where about $2 \mathrm{~m}$ of erosion occurred. Although island area increased by 300 percent since the devastation of Hurricane Katrina, the entire Breton platform lost $11.73 \times 10^{6} \mathrm{~m}^{3}$ since the 2007 survey (table 3). When comparing the subaerial areas of the DEMs, there are some discrepancies. In the earlier grids, land was assigned a uniform elevation of $+0.50 \mathrm{~m}$ (Miner and others, 2009). In the 2014 grid, land elevations were derived from lidar. Breton Island elevations in the $2014 \mathrm{DEM}$ average $0.52 \mathrm{~m} \pm 0.20 \mathrm{~m}$. The uniform elevations of the land areas in the older grids compared to the actual elevations in the 2014 grid affect volumetric comparisons; however, both the difference in averaged versus actual elevation and the number of grid nodes containing land values are very small. The departures in volumetric comparisons should be minimal when considering the order of magnitude in volume.

Like Breton Island, the Gosier Shoals show significant increase in elevation, derived from sediment eroded immediately offshore (fig. 13). Active migration of the shoals to the southwest was occurring, yet the Gosier platform experienced a net decrease $\left(-8.52 \times 10^{6} \mathrm{~m}^{3}\right)$ in sediment over this time period. After Hurricane Katrina, the MRGO ship channel was decommissioned and was no longer maintained; infilling of the channel can be clearly seen in figures 13 and 14. The channel is infilling at an average rate of $1.13 \times 10^{6} \mathrm{~m}^{3} / \mathrm{yr}$ (table 3). If the MRGO 1920-2014 volume change is an approximation of the material excavated to create the shipping channel, then the net deposition since 2007 suggests that within the study area, the channel is 73 percent infilled. Adding this volume to the 1920-2014 volume produces a net sediment volume within the channel of $20 \times 10^{6} \mathrm{~m}^{3}$. The MRGO was authorized as an 11-m-deep shipping channel that was $152 \mathrm{~m}$ wide at the base (U.S. Army Corps of Engineers, 2007). Within the study area, the channel is $12.6 \mathrm{~km}$ long. These dimensions provide an excavation volume of $21 \times 10^{6} \mathrm{~m}^{3}$, only a 5-percent difference from the volume measured through the seafloor change analysis.

\section{Elevation Profile Comparison}

A series of transects (figs. 15-19) parallel and perpendicular to the Breton/Gosier platforms have been constructed to directly represent the change in bathymetry over time (see figs. 6-9 for locations of transects for each time period). Transect locations were chosen from the bathymetric change models (figs. 10-13) to sample areas that show significant change over time.

Transects across the DEMs provide a profile comparison of the relative elevations between time periods. The transect (T0) along the axis of the island platform (see figs. 6-9 for location) shows the massive loss of island elevation across Breton's southern half between the 1920 and 2007 periods (fig. 15, location A). The profiles also demonstrate the consistent landward retreat of Breton Island over the years (fig. 15, location B). Observation of aerial photographs taken after storms (Westphal, 2009) verifies that comparison between the 1920 and 2007 profiles largely represents the disintegration of the island following Hurricanes Ivan and Katrina, with significant erosion of the island's flanks. Since then, some rollover and recovery have occurred (fig. 15, location B). In the area of the MRGO, the 2007 profile captures the designed channel, followed by infilling in 2014 (fig. 15, location C). Along the Gosier platform, the accretion of sediment on the terminal end of the platform (figs. 11, 12) is evident following 1869 (fig. 15, location D), and the emergence and southward migration of Gosier Shoals are evident in the 2007 and 2014 profiles (fig. 15, location E).

Onshore-offshore transect T1 (fig. 16) crosses the southern part of the Breton platform (see figs. 6-9 for location) and shows a consistent increase in elevation in the early years (fig. 16, loca- 


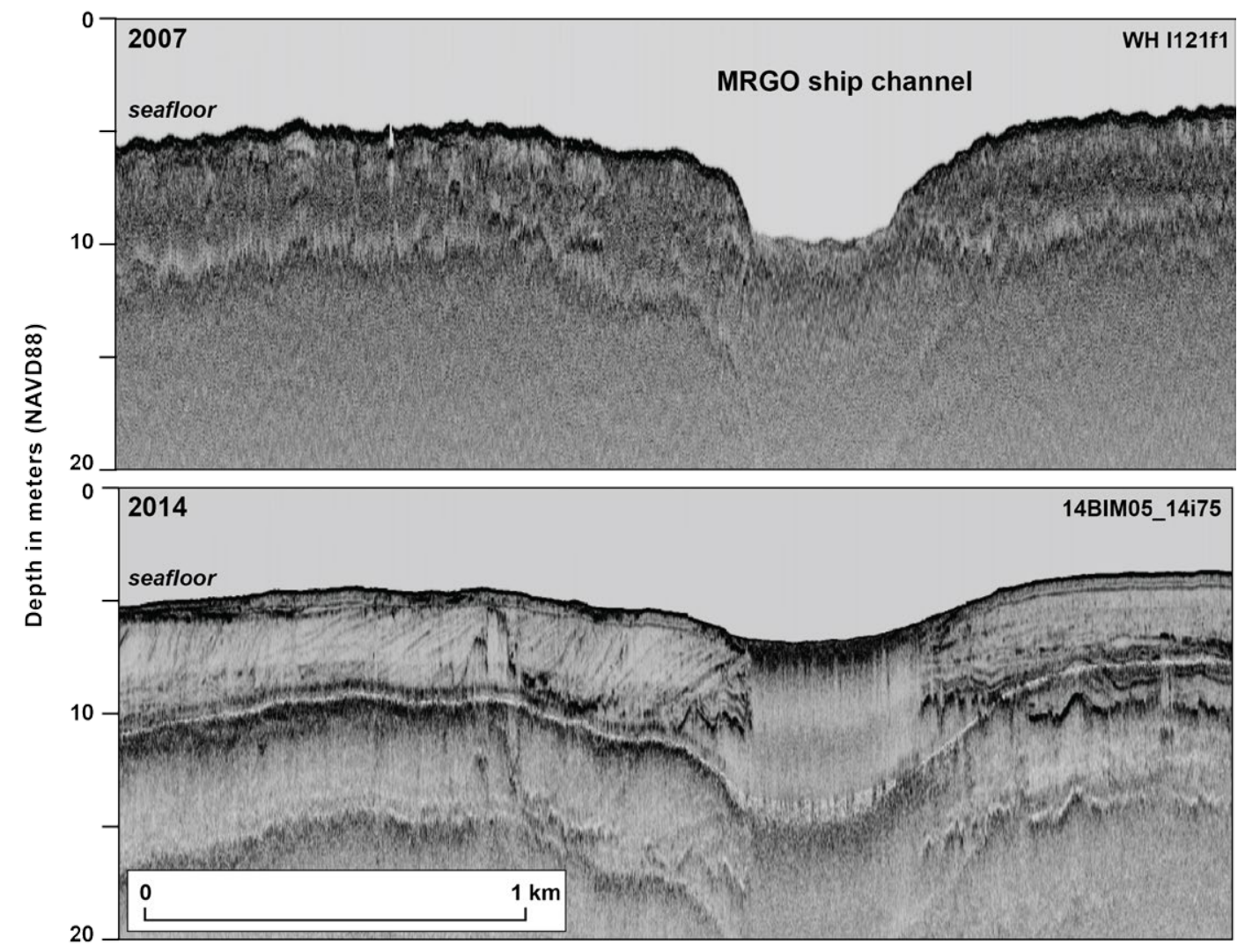

Figure 14. Seismic subbottom profiles collected in 2007 (top) and reoccupied in 2014 (bottom) across the Mississippi River-Gulf Outlet (MRGO) ship channel (see fig. 13 for location) reflect the infilling of the channel after its decommission and cease in maintenance dredging following Hurricane Katrina.

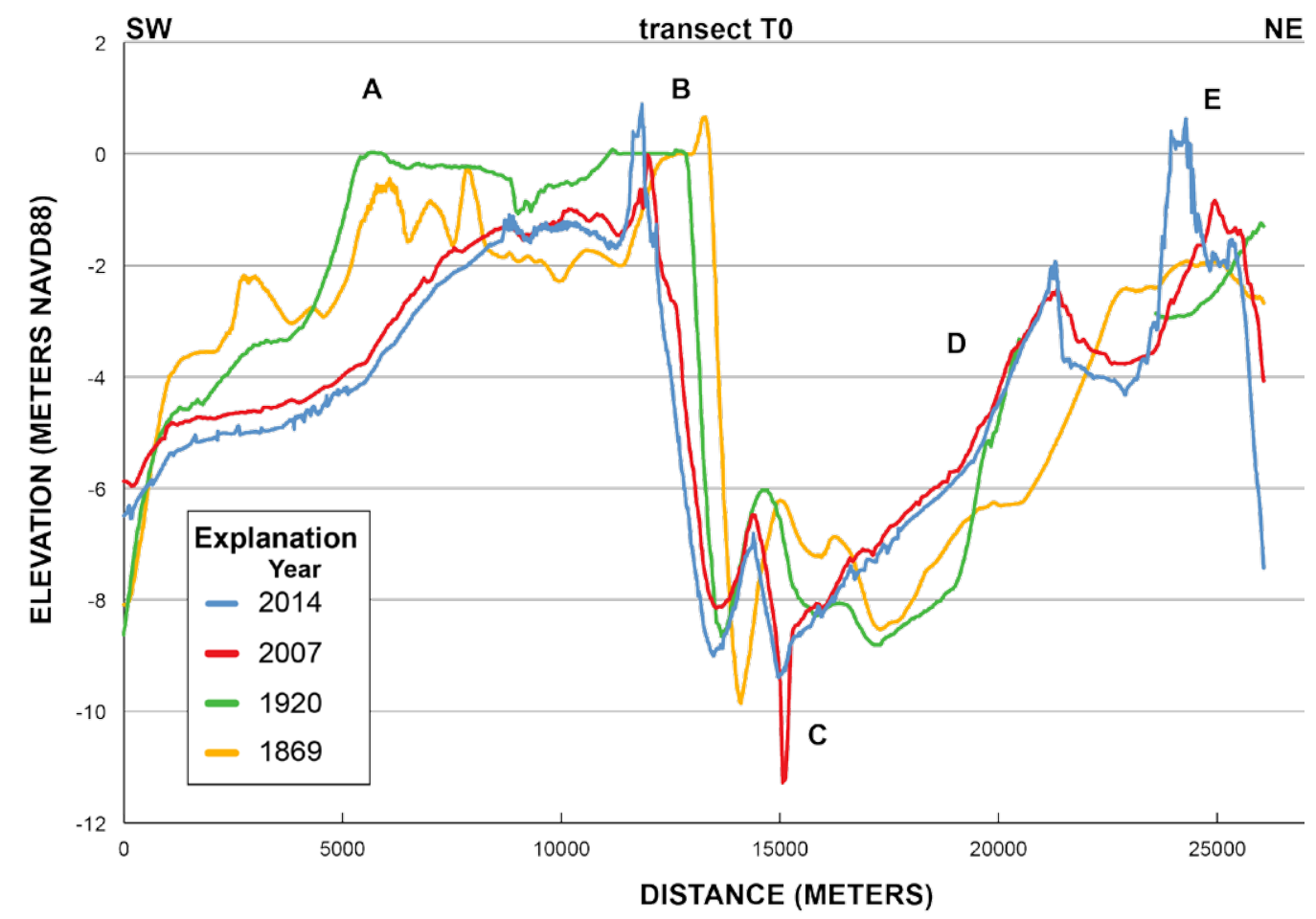

Figure 15. Elevation profiles derived from the digital elevation models for the four time periods across the Breton/Gosier platforms and for the Mississippi River-Gulf Outlet (transect T0, see figs. 6-9 for location during each time period). Vertical exaggeration is 1300x. 


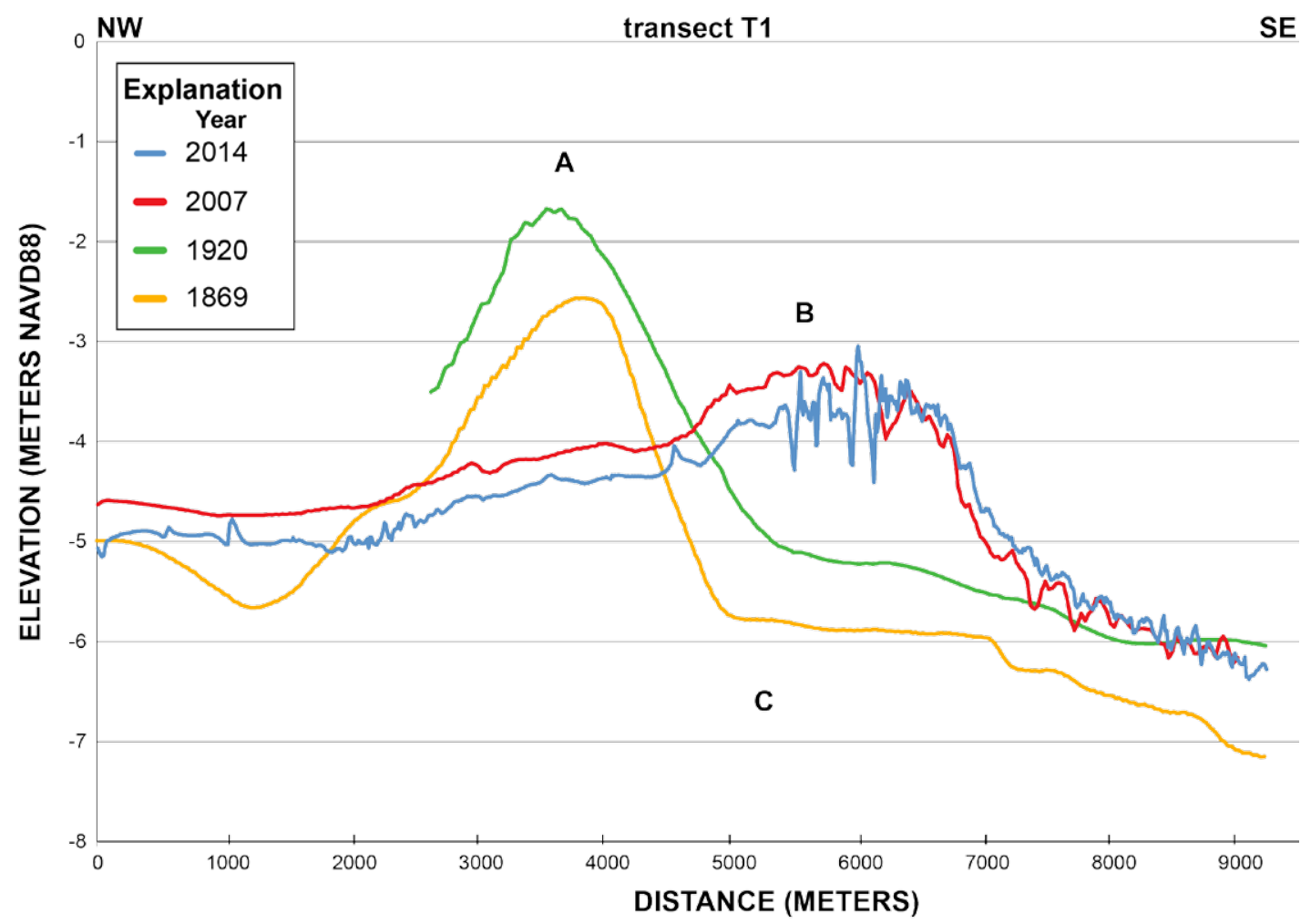

Figure 16. Elevation profiles derived from the digital elevation models for the four time periods across the southern Breton platform and offshore (transect T1, see figs. 6-9 for location during each time period). Vertical exaggeration is 790x.

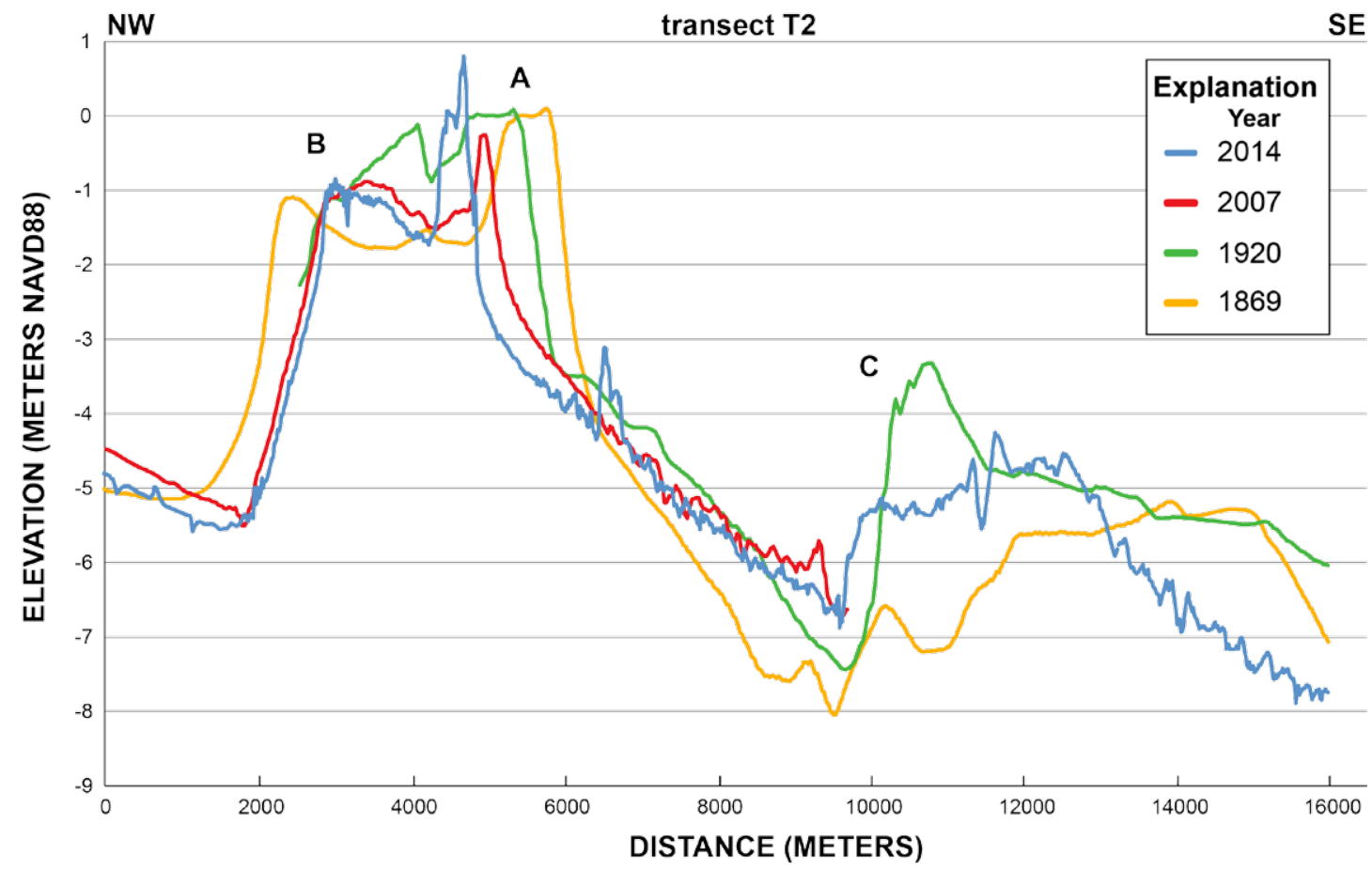

Figure 17. Elevation profiles derived from the digital elevation models for the four time periods across Breton island and the offshore shoal (transect T2, see figs. 6-9 for location during each time period). Vertical exaggeration is $975 \mathrm{x}$. 


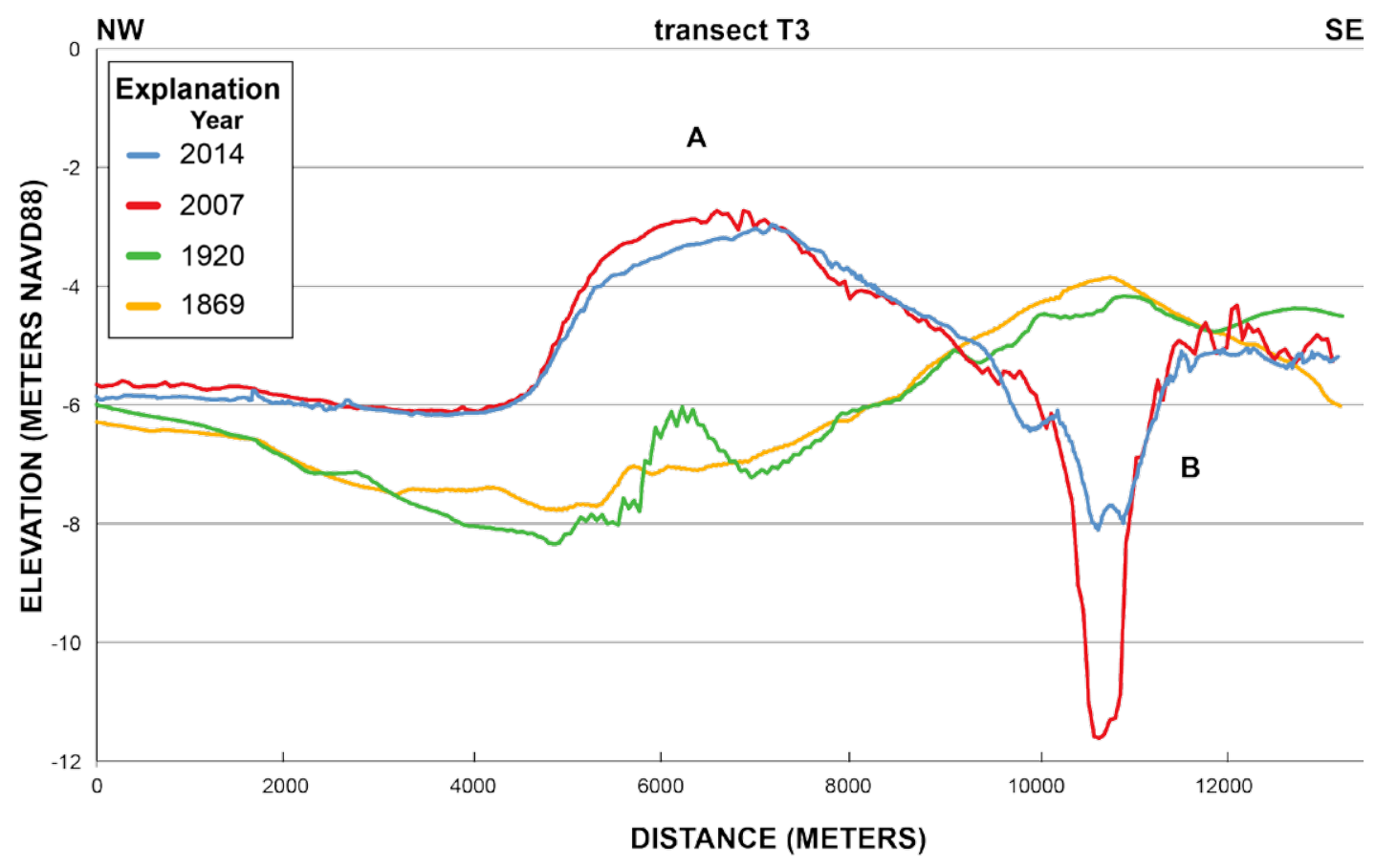

Figure 18. Elevation profiles derived from the digital elevation models for the four time periods across Breton Sound, the Gosier platform, the Mississippi River-Gulf Outlet, and the offshore shoal (transect T3, see figs. 6-9 for location during each time period). Vertical exaggeration is $635 \mathrm{x}$.

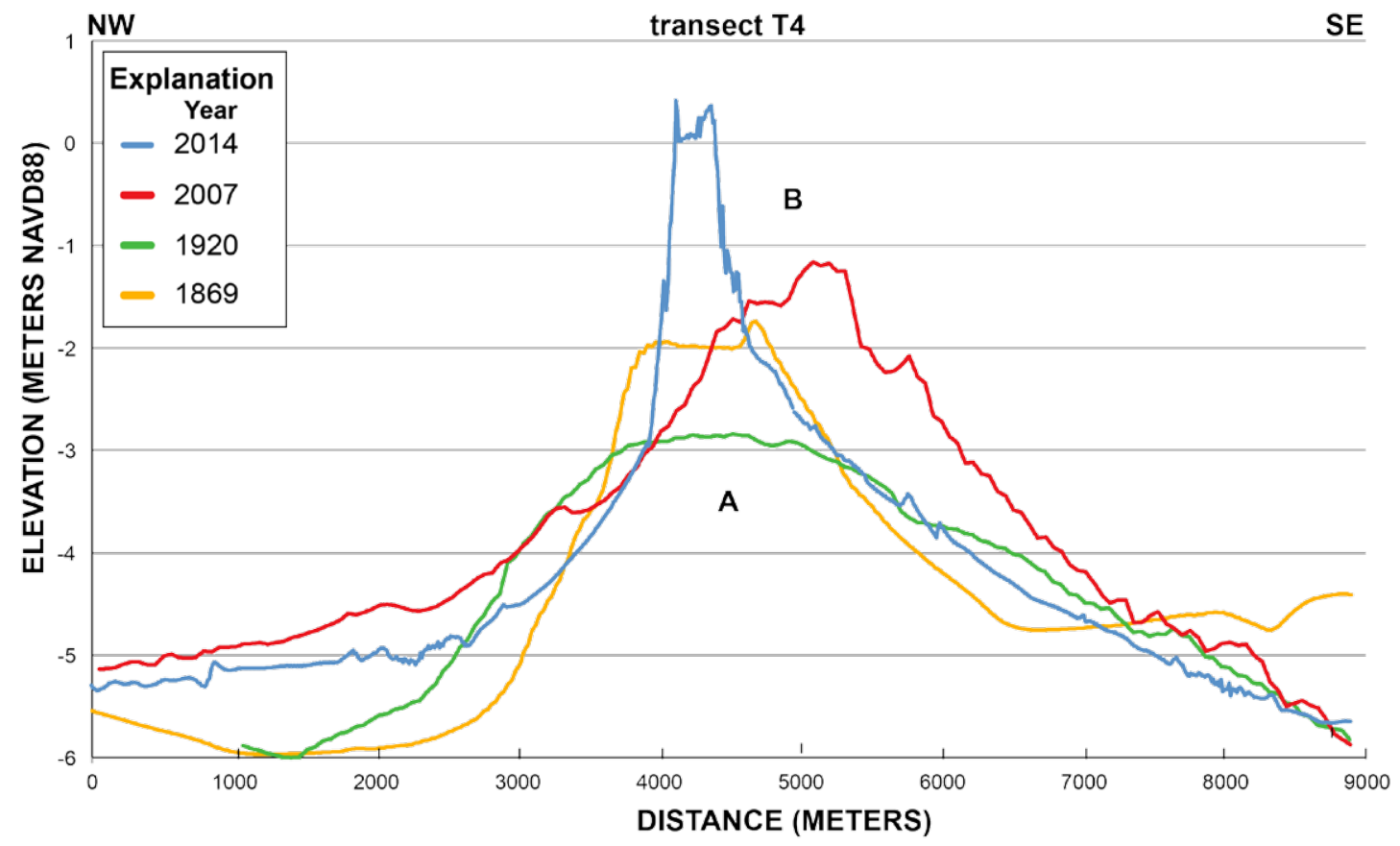

Figure 19. Elevation profiles derived from the digital elevation models for the four time periods across Breton Sound, Gosier Shoals, and offshore (transect T4, see figs. 6-9 for location during each time period). Vertical exaggeration is 720x. 
tion A). Following Hurricanes Ivan and Katrina, the island platform was severely eroded, and sediments were transported offshore (fig. 16, location B) and, to a lesser extent, to the sound-side of the island platform. The high resolution of the 2014 survey captures sandwaves represented by the high-frequency oscillations in the profile. Comparison of the 2007 and 2014 profiles shows continued loss of elevation in this area, with some slight migration offshore.

Onshore-offshore transect T2 (fig. 17) crosses the northern part of the Breton Island and platform (see figs. 6-9 for location). The profile shows the steady landward retreat over time and loss of elevation and eroded shorefaces following Hurricanes Ivan and Katrina (fig. 17, location A). The 2014 profile records the post-Katrina rollover and island emergence at this location. The sound-side of the island has been experiencing erosion since 1869, and comparing the 1920 profile to later years shows that elevation did not recover following Katrina (fig. 17, location B). The offshore shoal shows a landward shift over the past century and deflation in elevation since 1920 (fig. 17, location C). The area between the offshore shoal and island platform (Breton Gulf; table 3) accumulated $29.32 \times 10^{6} \mathrm{~m}^{3}$ of sediment (table 3) over the long-term (1870-2014), either from sediments derived from the offshore shoal and (or) erosion of the Breton platform.

Onshore-offshore transect T3 (fig. 18) extends across the southern end of the Gosier platform (see figs. 6-9 for location) where extensive deposition is evident at the terminal end of the platform (fig. 18, location A). Although the 1920 profile does not reflect significant accretion at this location, examination of the long-term accretion-erosion maps (figs. 10-12) shows this deposition has been occurring since 1869 and is not due to rapid deposition during the most recent extreme storms. The profile crosses the MRGO ship channel, and infilling of the channel since its decommission is evident (fig. 18, location B).

Onshore-offshore transect T4 (fig. 19) reflects the highly dynamic nature of the Gosier platform (see figs. 6-9 for location). Between the 1869 and 1920 surveys there was a decrease in elevation of the platform at this location with deposition along the margins (fig. 19, location A), but sediment loss was mainly due to transport of sediment to the terminal end of the platform (see previous discussion about transect T3). The 2007 profile reflects the significant transport of sediment offshore during Hurricanes Ivan and Katrina (fig. 19, location B) and some shedding of sediment to the sound-side of the platform. The 2014 profile shows dynamic storm recovery and the emergence of Gosier Shoals above sea level by moving sediment back onto the former platform (fig. 19, location B), ostensibly through normal wave action because no major storm events impacted the area during this time period. On the sound-side, adjacent to the Gosier platform, approximately $11.41 \times 10^{6} \mathrm{~m}^{3}$ of sediment has accumulated over the long term (table 3).

\section{Bathymetry and Sediment Composition}

Sediment samples collected in 2014 from the seafloor throughout the study area were analyzed for textural characteristics (for example, size and sorting). These characteristics are dependent in part on elevation. Figures 20 and 21 show the 2014 bathymetry overlain with mean grain size of the sediment samples and sediment sorting, respectively, plotted at each sample location. Sediment grain size is represented according to the Wentworth size class (Folk, 1968), which separates the sediment sizes into sand and silt fractions. The results show that the Breton and Gosier platforms and the offshore shoal contain the largest median grain size, typically as fine sand. Very fine sand occurs mainly along the periphery of the Breton platform and offshore shoal, and silt samples are found predominantly in the deeper waters off platform and within the MRGO. Presently the MRGO is infilling primarily with fluidized mud, sedi- 


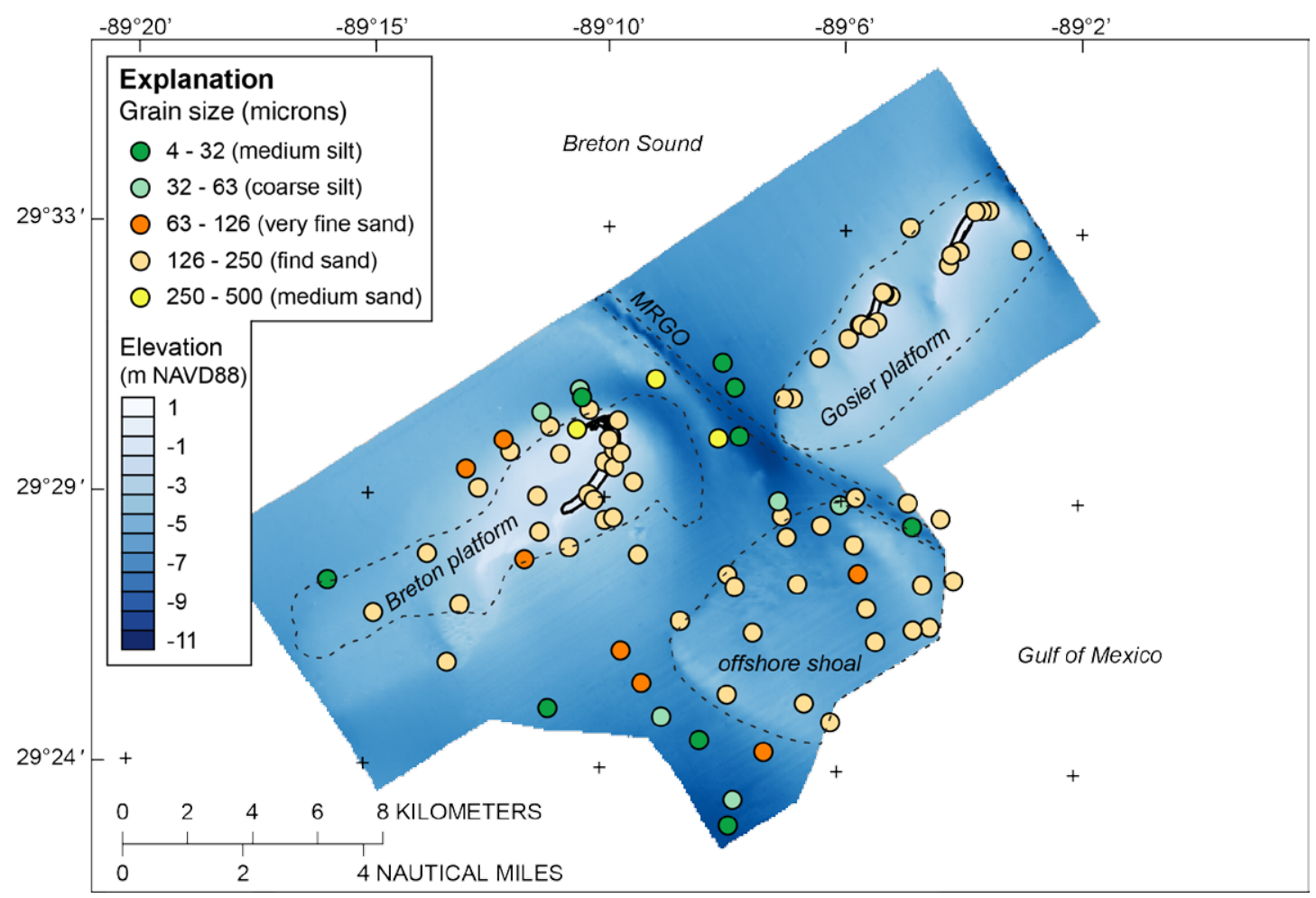

Figure 20. Average grain size of sediment samples collected from the seafloor within the Breton National Wildlife Refuge study area, colorcoded by size (in microns), with the accompanying Wentworth size classification (medium silt through medium sand). Sample locations plotted on the 2014 bathymetry.

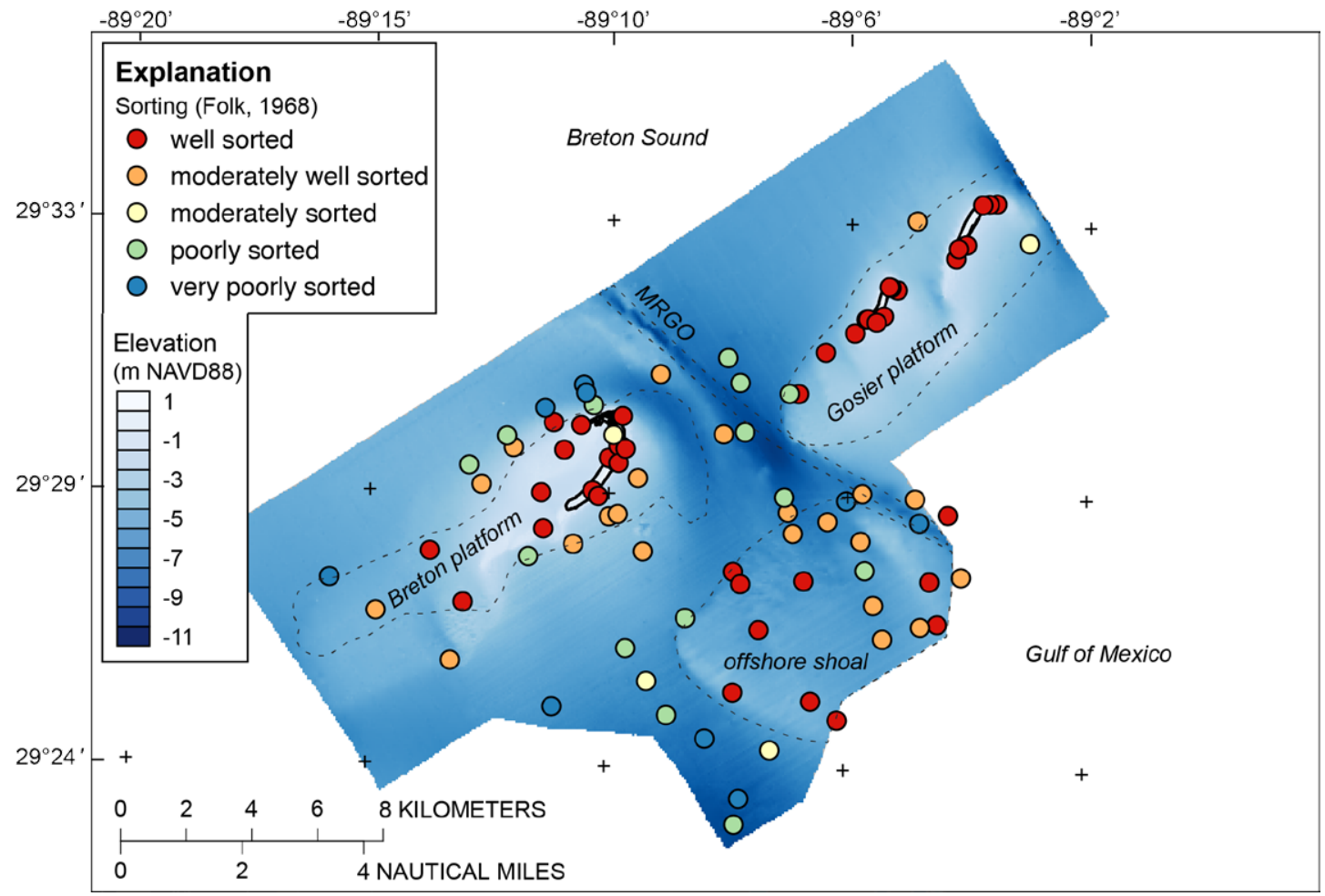

Figure 21. Sorting of sediment samples collected from the seafloor within the Breton National Wildlife Refuge study area, color-coded by the classification from Folk (1968). Sample locations plotted on the 2014 bathymetry. 
ment samples acquired from within the former channel are composed of silt and clay. Two sites within the natural tidal inlet adjacent to the MRGO contain medium-sized sand and represent preferential sorting of the coarser sized sand by tidal energy. Figure 21 shows sorting, or the standard deviation about the mean grain size, for 90 percent of the distribution (Folk, 1968). The results are divided into sorting classifications from well sorted (includes two very well sorted samples), to very poorly sorted. Sediment samples from Breton and Gosier platforms are predominantly well sorted, and sediment samples from the offshore shoal are predominantly well to moderately well sorted. The two samples that show medium sand within the tidal inlet (fig. 20) are moderately well sorted. Samples collected in deeper waters range in sorting but are predominantly poorly sorted. In summary, sediments within shallower water depths that are affected by wave action and areas of high tidal currents have higher median grain size (with naturally higher sand content) and are better sorted than the deeper, muddier sediments.

\section{Conclusions}

Breton Island, the surrounding platform, and the neighboring Gosier platform to the north are highly dynamic systems with respect to elevation change over the past century. Two other morphologic features within the study area also reflect change over the study period: a shoal located 5-11 kilometers $(\mathrm{km})$ offshore of Breton Island and the Mississippi River-Gulf Outlet (MRGO) shipping channel that bisects the Breton and Gosier platforms through a natural tidal channel (fig. 10). Seafloor change within the study area has primarily been caused by the erosion and deposition of sediments over time. The effects of land subsidence and eustatic sea-level rise are small compared to sediment dynamics over the 145-year observation period of this study. Seafloor change occurs relative to long-term wave processes, short-duration/high-energy storm impacts, and anthropogenic modifications. The influence of these parameters is observed by comparing bathymetric surveys from 1869, 1920, 2007, and 2014.

The long-term observation (1869-2014) represents all of these influences (fig. 10). The dramatic loss of island area, shoreface erosion, and landward rollover in island position are evident (figs. 2, 17 , location A). This movement is accompanied by erosion and redistribution of sediment from the island platform to the platform margins. The Gosier platform, although experiencing some erosion in the foreshore due to rollover, is dissimilar to the Breton platform in that accretion is dominant, occurring mainly on the southern terminal end of the platform. Most recently, the shoals on the Gosier platform have emerged (fig. 15). The offshore shoal has lost elevation during the study period, with sediment moving to the shoal flanks (fig. 10). It does not appear that the offshore shoal has contributed sediment to the Breton platform over this time period, although the area between the shoal and platform appears to be infilling (Breton Gulf, table 3).

The period from 1869 to 1920 represents natural morphologic change prior to the construction of the MRGO, and this is the only time period where the study area experienced net accretion in sediment. Over this half-century most of Breton Island remained relatively stationary, with only the northern half experiencing rollover (fig. 11). Erosion of the shoreface occurred at this location, yet the island platform prior to construction of the MRGO acquired a net gain of sediment (table 3). The Gosier platform accreted along its southern terminal end at roughly the same rate as during 1869-2014. The natural inlet prior to the MRGO experienced net loss of sediment through tidal scour, likely through increasing currents as the terminal end of the Gosier platform accreted into the tidal pass (fig. 11). This accretion continued until present while, following construction of the MRGO, the Breton platform underwent significant erosion (fig. 12). Similarly, the offshore shoal experienced erosion (figs. 12, 17, location C), losing twice as much as it gained during the previous half-century (table 3 ). 
In the short-term assessments, there is clear correlation between storm impact and loss of island area (fig. 4), particularly the dramatic loss of area during major storms Opal, Isidore, Ivan, and Katrina. Sand placement adjacent to the island did increase island area following Hurricane Georges, which significantly impacted the Chandeleur Island chain, yet was ephemeral and completely removed by the next major event (Hurricane Isidore). The bathymetric change analysis indicates that during these events sediment is transported offshore (fig. 19, location B). In the recovery years following storm impacts, some of this sediment is available to replenish the shoreface through sand-bar welding to the shoreface (fig. 17, location A, and fig. 19, location B). This is observed in the final years of the study when land accretion occurred on Breton Island (fig. 4) and the Gosier Shoals became emergent, derived from sediments eroded immediately offshore (fig. 13). Maintenance dredging of the MRGO ship channel has ceased following decommission and has infilled since Hurricane Katrina (figs. 13, 14, 15, location C, and 18, location B). This restoration of the seafloor elevation to natural conditions may strongly affect the sediment transport processes between the Gosier and Breton platforms and offshore, and warrants continued monitoring of seafloor change within this dynamic system.

\section{References Cited}

DeWitt, N.T., Fredericks, J.J, Flocks, J.G., Miselis, J. L., Locker, S. D., Kindinger, J. G, Bernier, J.C., Kelso, K. W., Reynolds, B.J., Wiese, D. S., and Browning, T.N., 2016, Archive of bathymetry and backscatter data collected in 2014 nearshore Breton and Gosier Islands, Breton National Wildlife Refuge, Louisiana: U.S. Geological Survey Data Series 1005, accessed June 30, 2016, at http://dx.doi.org/10.3133/ds1005.

Ellis, J., and Stone, G., 2006, Numerical simulation of net longshore sediment transport and granulometry of surficial sediments along Chandeleur Island, Louisiana, USA: Marine Geology, v. 232, p. 115-129.

Folk, R., 1968, Petrology of sedimentary rocks: Austin, Tex., Hemphill Publishing Company, 170 p.

Frazier, D., 1967, Recent deltaic deposits of the Mississippi River, their development and chronology: Transactions-Gulf Coast Association of Geological Societies, v. 17, p. 287-315.

Kindinger, J.L., Buster, N.A., Flocks, J.G., Bernier, J.C., and Kulp, M.A., 2013, Louisiana Barrier Island Comprehensive Monitoring (BICM) program summary report-Data and analyses 2006 through 2010: U.S. Geological Survey Open-File Report 2013-1083, 86 p.

Lavoie, Dawn, 2009, Executive summary, in Lavoie, Dawn, ed., Sand resources, regional geology, and coastal processes of the Chandeleur Islands coastal system-An evaluation of the Breton National Wildlife Refuge: U.S. Geological Survey Scientific Investigations Report 2009-5252, p. 1-6.

Lavoie, Dawn, Flocks, J.G., Kindinger, J.L., Sallenger, A.H., Jr., and Twichell, D.C., 2010, Effects of building a sand barrier berm to mitigate the effects of the Deepwater Horizon oil spill on Louisiana marshes: U.S. Geological Survey Open-File Report 2010-1108, 7 p.

List, J.H., Jaffe, B.E., Sallenger, A.H., Jr., Williams, S.J., McBride, R.A., and Penland, Shea, 1994, Louisiana Barrier Island Erosion Study: Atlas of sea-floor changes from 1878 to 1989: U.S. Geological Survey and Louisiana State University, Miscellaneous Investigations Series I-2150-B, 81 p.

Louisiana Department of Natural Resources, 2013, FTP directory /bicm//Vol3 — Bathymetry, accessed April 26, 2016, at ftp://ftp.dnr.state.la.us/bicm/Vol3--Bathymetry. 
Miner, M., Kulp, M.A., Penland, S., Weathers, D., Motti, J., McCarty, P., Brown, M., Martinez, L., Torres, J., Flocks, J., Dewitt, N., Ferina, N., Reynolds, B.J., Twichell, D., Baldwin, W., Danforth, B., Worley, C., and Bergeron, E., 2009, Louisiana barrier-island comprehensive monitoring program (BICM) - Volume 3, Bathymetry and historical seafloor change 1869-2007-Part 1, Bathymetry methods and error analysis: Prepared for the Louisiana Department of Natural Resources, Coastal Restoration Division, by the University of New Orleans, Pontchartrain Institute for Environmental Sciences, New Orleans, Louisiana, 45 p.

Morgan, K.L.M., 2015, Baseline coastal oblique aerial photographs collected from Navarre Beach, Florida, to Breton Island, Louisiana, September 1, 2014: U.S. Geological Survey Data Series 952, accessed March 31, 2016, at http://dx.doi.org/10.3133/ds952.

Morton, R., 2008, Historical changes in the Mississippi-Alabama barrier-island chain and the roles of extreme storms, sea level, and human activities: Journal of Coastal Research, v. 24, no. 6, p. 1587-1600.

Penland, S., and Boyd, R., 1981, Shoreline changes on the Louisiana barrier coast: Institute of Electrical and Electronics Engineers, p. 209-219.

Penland, S., Boyd, R., and Suter, J., 1988, Transgressive depositional systems of the Mississippi Delta Plain-A model for barrier shoreline and shelf sand development: Journal of Sedimentary Petrology, v. 58 , no. 6 , p. $932-949$.

Penland, S., and Ramsey, K.E., 1990, Relative sea-level rise in Louisiana and the Gulf of Mexico-1908-1988: Journal of Coastal Research, v. 6, no. 2, p. 323-342.

Penland, S., Westphal, K.A., Zganjar, C., Connor, P., Tao, Q., Mathies, L., Nord, B., and Gunn, R., 1997, Part 4: Results of monitoring the beneficial use of dredged material at MRGO - Breton Island-Base year 1985 thru fiscal year 1996: Beneficial Use Monitoring Program, U.S. Army Corps of Engineers, New Orleans District, 18 p.

Rogers, B., Kulp, M., and Miner, M., 2009, Late Holocene chronology, origin, and evolution of the St. Bernard Shoals, Northern Gulf of Mexico, USA: Geo-Marine Letters, v. 29, p. 379-394.

Terrano, J.F., Flocks, J.G., and Smith, K.E.L., 2015, A GIS Compilation of Vector Shorelines and Associated Shoreline Change Data for Breton Island, Louisiana: 1869-2014: U.S. Geological Survey data release, accessed April 22, 2016, at http://dx.doi.org/10.5066/F7XS5SGM.

Terrano, J.F., Flocks, J.G., and Smith, K.E.L., 2016a, Analysis of shoreline and geomorphic change for Breton Island, Louisiana, from 1869 to 2014: U.S. Geological Survey Open-File Report 2016-1039, 34 p., accessed April 22, 2016, at http://dx.doi.org/10.3133/ofr20161039.

Terrano, J.F., Flocks, J.G., and Smith, K.E.L., 2016b, Topobathymetric lidar survey of Breton and Gosier Islands, Louisiana, January 16 and 18, 2014: U.S. Geological Survey data release, accessed April 22, 2016, at http://dx.doi.org/10.5066/F70G3H6G.

U.S. Army Corps of Engineers, 2007, Integrated final report to Congress and legislative environmental impact statement for the Mississippi River-Gulf Outlet Deep-Draft De-Authorization Study: U.S. Army Corps of Engineers, New Orleans District, 147 p. 
Westphal, K., 2009, Louisiana barrier-island comprehensive monitoring program (BICM) — Volume 1, Barrier-shoreline post-storm assessment-Part 4, Historic photo-pairs/time series: Prepared for the Louisiana Department of Natural Resources, Coastal Restoration Division, by the University of New Orleans, Pontchartrain Institute for Environmental Sciences, New Orleans, Louisiana, 38 p.

Williams, S.J., Penland, S., and Sallenger, A.H., Jr., eds., 1992, Louisiana Barrier Island Erosion Study-Atlas of shoreline changes from 1853 to 1989: U.S. Geological Survey Miscellaneous Investigation Series I-2150-A, 103 p. 
